\title{
Effects of berry seed residues on ruminal fermentation, methane concentration, milk production, and fatty acid proportions in the rumen and milk of dairy cows
}

\author{
Magdalena Bryszak, ${ }^{1}$ Malgorzata Szumacher-Strabel, ${ }^{1}$ Mohamed El-Sherbiny, ${ }^{2}$ Anna Stochmal, ${ }^{3}$ \\ Wieslaw Oleszek, ${ }^{3}$ Edward Roj, ${ }^{4}$ Amlan Kumar Patra, ${ }^{5}$ and Adam Cieslak ${ }^{1 *}$ \\ ${ }^{1}$ Department of Animal Nutrition, Poznan University of Life Sciences, Wolynska 33, 60-637 Poznan, Poland \\ ${ }^{2}$ Department of Dairy Sciences, National Research Centre, 33 Bohouth St., Dokki, 12622 Giza, Egypt \\ ${ }^{3}$ Department of Biochemistry, Institute of Soil Science and Plant Cultivation, State Research Institute, Czartoryskich 8, 24-100 Pulawy, Poland \\ ${ }^{4}$ New Chemical Syntheses Institute, Al. Tysiaclecia Panstwa Polskiego 13a, 24-110 Pulawy, Poland \\ ${ }^{5}$ Department of Animal Nutrition, West Bengal University of Animal and Fishery Sciences, 37 K. B. Sarani, Kolkata, India
}

\section{ABSTRACT}

Strawberry (SB), black currant (BC), and raspberry seed $(\mathrm{RB})$ residues were used in 3 experiments to study their effects on ruminal fermentation, methane concentration, and fatty acid (FA) proportions in the ruminal fluid and milk of dairy cows. Initially, a batch fermentation in vitro study (experiment 1) was performed to investigate the effects of the 3 berry residues on basic ruminal fermentation parameters. Total volatile fatty acid concentrations, including acetate, propionate, and butyrate, increased in the BC group compared with other treatments. Based on the preliminary in vitro results, 2 consecutive in vivo experiments were conducted using 4 Polish Holstein-Friesian cows fitted with rumen cannulas (experiment 2) and 30 lactating Polish Holstein-Friesian dairy cows (experiment 3 ) in a replicated $2 \times 2$ crossover design. Cows in both experiments received a partial mixed ration (PMR) in 2 variants: (1) a control diet of PMR $+2 \mathrm{~kg}$ of concentrate (control); (2) PMR $+2 \mathrm{~kg}$ of $\mathrm{BC}$ seed residues $(\mathrm{BC})$. The $\mathrm{BC}$ diet did not mitigate ruminal methane production. Ruminal fermentation (experiment 2) was not affected by the BC diet; however, the concentrations of C18:1 trans-11 and C18:2 cis-9,trans-11 increased significantly by 91 and $131 \%$, respectively. Likewise, concentrations of total trans $\mathrm{C} 18: 1$ and total monounsaturated FA in ruminal fluid were increased significantly by BC seed residues. In experiment $3, \mathrm{BC}$ significantly increased milk fat C18:1 trans-11, C18:2 cis-9,trans-11, n-3, n-6, and polyunsaturated FA concentrations without affecting milk production performance. In conclusion, the amount

Received July 3, 2018.

Accepted October 10, 2018.

*Corresponding author: adam.cieslak@up.poznan.pl
$(2 \mathrm{~kg} / \mathrm{d})$ of $\mathrm{BC}$ used in this study did not adversely affect ruminal fermentation or milk production and composition. However, using BC increased proportions of unsaturated FA and conjugated linoleic acid in milk. Although dietary $\mathrm{BC}$ did not exert a strong methane inhibition effect, it could represent an inexpensive alternative concentrate to improve beneficial FA in milk without negative effects on rumen fermentation and production parameters in dairy cows. Incorporation of berry seed residues in diets would be profitable economically and nutritionally for dairy cattle production. Key words: berry, dairy cow, fermentation, fatty acid composition, milk production

\section{INTRODUCTION}

Poland represents one of the largest producers of berries in the world. According to the Food and Agriculture Organization of the United Nations, Poland produced 196,972 t of strawberries (Fragaria $\times$ ananassa Duchesne), 166,110 t of currants (Ribes nigrum and Ribes rubrum), and 129,063 t of raspberries (Rubus idaeus) in 2016 (FAOSTAT, 2016). It is estimated that the total production of all types of berries is about $523,443 \mathrm{t}$ in cultivated areas of 143,953 ha (FAOSTAT, 2016). During processing of berry fruits, large amounts of waste by-products are produced and used for composting or combustion (Roj et al., 2009; Szumacher-Strabel et al., 2011).

The EU Directive 75/442/EEC for a common European Union policy on the management and utilization of bio-wastes encourages the recovery of waste materials including fruit industry waste by-products to conserve natural resources and reduce environmental pollution. In recent years, a lot of attention has been paid to issues related to the presence of natural and biologically active substances in animal feeds, which would 
enrich products of animal origins and at the same time improve animal health. Berry fruits and their byproducts contain many biologically active substances such as tannins, saponins, flavones, phenolic acids, ellagic acid, vitamins $\mathrm{C}$ and $\mathrm{E}$, folic acid, and $\beta$-sitosterol that can be exploited in animal nutrition (Roj et al., 2009). In ruminants, these biologically active substances may stimulate microbial metabolism in the rumen (Broudiscou et al., 2002) and increase the digestibility of nutrients (Patra, 2010). Moreover, they may improve ruminal fermentation and reduce incidences of ruminal acidosis by increasing the numbers of lactate-consuming bacteria (e.g., Megasphaera elsdenii) in the rumen (Balcells et al., 2012). The biologically active substances modulating microbial populations and fermentation in the rumen (Lazze et al., 2003; Szumacher-Strabel and Cieslak, 2010) may also be considered as an effective strategy in mitigation of methane production (Wang et al., 2009; Patra and Saxena, 2010).

The bioactive substances may also modulate ruminal fatty acid (FA) biohydrogenation leading to changes in rumen and milk FA profile (Henke et al., 2017). For instance, quebracho condensed tannins inhibit one of the bacterial species involved in ruminal biohydrogenation, Butyrivibrio proteoclasticus (Buccioni et al., 2015) and consequently may improve the quality of milk by increasing UFA contents (Henke et al., 2017). The possibility of using berry by-products in animal nutrition may allow for the production of healthy animal-derived foods and mitigation of enteric methane emission, hence an environmentally friendly production system. Therefore, the present experiments were undertaken to evaluate the effects of berry fruit seed residues on in vitro and in vivo ruminal fermentation processes, milk production, and composition. We hypothesized that the berry seed residues may replace a part of the concentrate in diets of dairy cows while beneficially modulating rumen fermentation, decreasing methane production, and improving the FA proportions in the ruminal fluid and milk of dairy cows.

\section{MATERIALS AND METHODS}

The residues of strawberry (SB), black currant (BC), and raspberry (RB) seeds were investigated for their effects on ruminal fermentation and milk production performance of cows in 3 successive experiments: an in vitro ruminal fermentation study (experiment 1 ), an in vivo ruminal fermentation study using 4 cannulated cows (experiment 2), and a milk production performance study using 30 lactating dairy cows on a commercial farm (experiment 3). All experimental procedures were performed in accordance with the guidelines of the National Ethical Commission for Animal
Research (Ministry of Science and Higher Education, Poland).

\section{Experimental Materials}

Fresh fruits of $\mathrm{SB}, \mathrm{BC}$, and $\mathrm{RB}$ harvested from the south-east region of Poland were used for concentrated juice production at Alpex company (Łęczeszyce 120, Belsk Duży, Poland). The dry fruit seeds were collected after separation from dried pomace and were used for extraction of oil using supercritical $\mathrm{CO}_{2}$ as a solvent in a pilot plant (New Chemical Syntheses Institute, Puławy, Poland). Briefly, the seeds of SB, BC, and RB were crushed separately and loaded into an extractor. Subsequently, the extraction was carried out in a supercritical state using $\mathrm{CO}_{2}$ as a solvent. The extracted oil fraction of each fruit was collected in a one-stage separator. After extraction, the solid residues of SB, $\mathrm{BC}$ and $\mathrm{RB}$ were separately driven by a pneumatic transporter to a storage tank, where they were collected for investigation in this study.

\section{Experimental Design, Diet, and Management}

In Vitro Experiment. An in vitro batch culture fermentation experiment was carried out to study the effect of partially replacing a concentrate with seed residues of $\mathrm{SB}, \mathrm{BC}$, and $\mathrm{RB}$ on the ruminal fermentation characteristics and methane production (experiment 1 ). The fresh ruminal inoculum was collected from 4 Polish Holstein-Friesian dairy cows $(650 \pm 30 \mathrm{~kg})$ fitted with ruminal cannula before morning feeding. One month before the start of the in vitro experiment, the dairy cows were offered a TMR (Table 1). The average feed intake was controlled daily and each cow was fed $21 \mathrm{~kg}$ of DM. The fresh TMR was provided twice a day at 0600 and $1800 \mathrm{~h}$.

Ruminal content (approximately $400 \mathrm{~g}$ ) from each cow was collected from the top, bottom, and middle parts of the rumen. The rumen content for each cow was separately squeezed through 4 layers of cheesecloth, pooled in equal proportions, and again filtered through 4 layers of cheesecloth into a bottle (Schott North America Inc., Elmsford, NY) without headspace for inoculum. The ruminal fluid was quickly transported to the laboratory, keeping the bottle in a water bath maintained at $39^{\circ} \mathrm{C}$. The in vitro fermentation experiment was completed in 2 separate runs on different days with 6 incubation bottles per run for each substrate as described previously (Szumacher-Strabel et al., 2011). Additionally, 6 bottles in each run containing buffered ruminal fluid only were included as a blank control. In brief, ruminal fluid was diluted with a buffer solution at a ratio of 1:4. Then, the buffered ruminal fluid 
Table 1. Ingredient and chemical composition of diets and supplements fed to dairy cows ${ }^{1}$

\begin{tabular}{|c|c|c|c|}
\hline Item & TMR & PMR & Concentrate \\
\hline \multicolumn{4}{|c|}{ Ingredient composition, $\mathrm{g} / \mathrm{kg}$ of $\mathrm{DM}$} \\
\hline Maize silage & 392 & 429 & - \\
\hline Lucerne silage & 70 & 77 & - \\
\hline Grass silage & 103 & 112 & - \\
\hline Beet pulp & 112 & 122 & - \\
\hline Brewer's grain & 84 & 92 & - \\
\hline Extracted rapeseed meal & 42 & 46 & - \\
\hline Concentrate & 187 & 112 & - \\
\hline Mineral-vitamin mixture & 10 & 10 & - \\
\hline \multicolumn{4}{|c|}{ Chemical composition, $\mathrm{g} / \mathrm{kg}$ of DM } \\
\hline $\mathrm{OM}$ & 905 & 911 & 913 \\
\hline Ash & 92.2 & 89.7 & 87.3 \\
\hline $\mathrm{CP}$ & 167 & 157 & 210 \\
\hline $\mathrm{EE}$ & 25.5 & 23.2 & 29.1 \\
\hline aNDF & 366 & 392 & 303 \\
\hline \multicolumn{4}{|c|}{ Fatty acid (FA), $\mathrm{g} / 100 \mathrm{~g}$ of $\mathrm{FA}$} \\
\hline C14:0 & 0.82 & 0.78 & 0.29 \\
\hline C16:0 & 21.3 & 20.9 & 17.8 \\
\hline C18:0 & 4.35 & 4.73 & 3.25 \\
\hline C18:1 cis-9 & 19.6 & 18.9 & 26.8 \\
\hline $\mathrm{C} 18: 2$ cis- 9, cis -12 & 41.1 & 40.7 & 43.4 \\
\hline C18:3 cis-9,cis-12,cis-15 & 8.83 & 9.58 & 3.29 \\
\hline Other $\mathrm{FA}^{2}$ & 3.62 & 4.62 & 5.17 \\
\hline SFA & 29.0 & 29.0 & 24.4 \\
\hline UFA & 71.0 & 71.0 & 75.6 \\
\hline MUFA & 20.1 & 19.4 & 27.4 \\
\hline PUFA & 50.9 & 51.6 & 48.2 \\
\hline n-6 FA & 41.5 & 42.2 & 44.3 \\
\hline n-3 FA & 9.44 & 10.2 & 4.04 \\
\hline
\end{tabular}

${ }^{1} \mathrm{PMR}=$ partial mixed ration; $\mathrm{EE}=$ ether extract; $\mathrm{aNDF}=$ neutral detergent fiber determined with amylase. ${ }^{2}$ Other FA include C12:0, C14:1, C16:1, C18:1 cis-11, C18:1 cis-15, and C20:3n-6.

$(40 \mathrm{~mL})$ was transferred into $125-\mathrm{mL}$ glass incubation bottles (Midland Scientific Inc., Omaha, NE) containing $400 \mathrm{mg}$ of the substrate (DM basis). The control group consisted of a homogeneous mixture of ground meadow hay (240 $\mathrm{mg}$ of DM) and ground barley meal (160 mg of DM). In the experimental groups, ground barley grains ( $8 \mathrm{mg}$; i.e., $5 \%$ barley) were replaced by equivalent amounts $(8 \mathrm{mg})$ of seed residues of SB, BC, and RB, respectively. Subsequently, $400 \mathrm{mg}$ of the dried substrate was added to each bottle. After the buffered fluid was transferred to the bottles, they were filled with $\mathrm{CO}_{2}$, closed with a rubber stopper, sealed with aluminum covers, and incubated in an incubator (Galaxy 170R, Eppendorf North America Inc., Hauppauge, $\mathrm{NY}$ ) for $48 \mathrm{~h}$ anaerobically at a temperature of $39^{\circ} \mathrm{C}$. The bottles were automatically agitated every $30 \mathrm{~min}$ during incubation period. Fermented fluid samples were obtained at 8,24 , and $48 \mathrm{~h}$ of incubation to determine concentrations of VFA $(1 \mathrm{~mL})$ and ammonia $(5 \mathrm{~mL})$, and number of protozoa $(1 \mathrm{~mL})$ and bacteria $(20 \mu \mathrm{L})$. The gas samples $(500 \mu \mathrm{L})$ were collected from the headspace of the bottles in a gas-tight syringe for measurement of methane concentration in gas samples. The in vitro dry matter digestibility (IVDMD) was determined after $48 \mathrm{~h}$ of incubation.
In Vivo Experiment Using Cannulated Dairy Cows. In experiment 1, BC seed residues did not show any adverse effects on ruminal fermentation characteristics; thus, it was selected for in vivo study on ruminal fermentation and microbial population in lactating dairy cows (experiment 2). Four ruminal cannulated Polish Holstein-Friesian cows (multiparous, $650 \pm 30$ $\mathrm{kg}$ of $\mathrm{BW} ; 5-6 \mathrm{mo}$ in lactation) were allocated to 2 dietary groups (control and $\mathrm{BC}$ seed residues; $\mathrm{n}=4$ ) in a replicated $2 \times 2$ crossover design of 2 periods. Each period lasted $26 \mathrm{~d}$, with a 21-d adaptation and a 5-d sampling period. The control group was fed a partial mixed ration (PMR) along with $2 \mathrm{~kg} / \mathrm{d}$ of concentrate feed (Table 1). The concentrate feed was fed separately. In the experimental group, cows were fed the same PMR and $2 \mathrm{~kg} / \mathrm{d}$ of $\mathrm{BC}$ seed residues. Feeds were fed twice daily at 0600 and 1800 h. During the first $8 \mathrm{~d}$ of feeding, PMR was fed for ad libitum intake in both groups. Thereafter, all cows were provided restricted amounts of feeds, which was $95 \%$ of the daily feed intake based on previous $5 \mathrm{~d}$ to avoid effects of DMI on ruminal fermentation. During the experimental period, cows consumed $21.0 \pm 0.4 \mathrm{~kg}$ of DM daily. Drinking water was offered ad libitum. The rumen fluid was obtained before the morning feeding 
from each cannulated cow for determination of ruminal fermentation characteristics and FA profile and estimation of methane production. Additionally, during the sampling period, total feces were collected and weighed and $100 \mathrm{~g}$ of feces was sampled for determination of $\mathrm{DM}$ and $\mathrm{CP}$ digestibility.

In Vivo Experiment Using Dairy Cows Kept Under Commercial Conditions (Experiment 3). In experiment 3 , the period (total $26 \mathrm{~d}$ with a $21-\mathrm{d}$ adaptation and a 5-d sampling) and organization (replicated $2 \times 2$ crossover design) were the same as in experiment 2. Thirty multiparous Polish HolsteinFriesian lactating dairy cows $(650 \pm 45 \mathrm{~kg}$ of BW; $5-6$ mo in lactation) were equally and randomly allocated to 2 dietary groups (control and $\mathrm{BC} ; \mathrm{n}=30 ; 15$ in each group). The diets were the same as used in experiment 2 , where cows in the $\mathrm{BC}$ group were fed 2 $\mathrm{kg} / \mathrm{d}$ of BC seed residue instead of the $2 \mathrm{~kg} / \mathrm{d}$ of concentrate offered to the control group. Fresh PMR was offered twice daily at 0600 and $1800 \mathrm{~h}$, whereas both the concentrate and $\mathrm{BC}$ seed residue were supplied by a computer controlled feeder station (type FP 204, De Laval, Tumba, Sweden). The concentrate and BC residues were completely consumed by cows. The daily DMI for each group was maintained at $21.0 \pm 0.4 \mathrm{~kg}$ during the experiment. Cows were usually milked twice daily at 0530 and $1730 \mathrm{~h}$ and daily milk production was measured using a milk meter (WB Ezi-Test Meter 33 kg; Tru-Test Limited, Manukau, New Zealand). During the sampling days (last $5 \mathrm{~d}$ of each period), milk samples were obtained at each milking and daily milk samples were pooled proportionately based on morning and evening milk production. The daily pooled milk samples for each cow were again composited for $5 \mathrm{~d}$. Finally, the 5-d composite samples for each cow were divided in 2 parts: one part for analysis of basic milk constituents directly and other part for determination of milk FA composition, which was stored at $-20^{\circ} \mathrm{C}$ until analysis.

\section{Laboratory Analyses}

Chemical Composition of Feeds. Samples of TMR, PMR, concentrate, SB, BC, and RB seed residues were analyzed following the procedures of AOAC (2007) for DM (method no. 934.01), CP (using a KjelFoss Automatic 16210 analyzer; method no. 976.05), ash (method no. 942.05), crude fiber (CF; using FOSS Tecator, Fibertec System, method no. 962.09), and ether extract (EE; using a Soxhlet System HT analyzer; method no. 973.18) concentrations. Organic matter was calculated by subtracting ash concentration from DM content. Nitrogen-free extract was estimated by deducting concentrations of crude fiber, CP, EE, and ash from DM content.

The extracts containing phenolic compounds were prepared from powdered berry seed residues (Stochmal and Oleszek, 2007) to analyze tannin, flavonoid, and anthocyanin content. The flavonoids and anthocyanins in the extracts were determined on a HPLC with kaempferol glucoside as a standard (Janda et al., 2007). The liquid chromatography-MS technique was also used for identification and determination of tannins (Janda et al., 2007). The amount of tannins was calculated using (+)-catechin as an external standard.

Determination of Ruminal Fermentation Characteristics. Immediately after sample collection, $\mathrm{pH}$ values in ruminal fluid samples were determined using a pH meter (Type CP-104, Elmetron, Zabrze, Poland). The ammonia concentration was measured following a colorimetric Nessler method described previously (Szumacher-Strabel et al., 2011). For determination of IVDMD, the contents of the incubation flasks was transferred to previously weighed crucibles at the end of incubation. The residues were washed with distilled water thoroughly and dried at $105^{\circ} \mathrm{C}$ for 3 d. The percentage loss in weight of the feed DM in microbial fermentation process was expressed as IVDMD. The VFA concentrations were determined following a method described by Tangerman and Nagengast (1996) with some modifications. In brief, 3.6-mL ruminal fluid samples were preserved immediately after collection with $0.4 \mathrm{~mL}$ of $\mathrm{HgCl}_{2}$ solution $(46 \mathrm{mM})$ and stored at $-20^{\circ} \mathrm{C}$ until analysis of VFA on a gas chromatograph (GC Varian CP 3380, Sugarland, TX) equipped with a capillary column $(30 \mathrm{~m} \times 0.25 \mathrm{~mm}$; Agilent HP-Innowax, 19091N-133, Agilent Technologies, Santa Clara, CA) and a flame ionization detector. The concentrations of individual VFA were determined using an external VFA standard prepared by mixing individual VFA (Sigma-Aldrich, St. Louis, MO).

Methane Production. Methane concentration in experiment 1 was measured by a gas chromatograph (SRI PeakSimple model 310; Alltech Inc, Nicholasville, $\mathrm{KY}$ ) using appropriate gas standards (mix gases of $5.63 \% \mathrm{CO}_{2}, 5.56 \% \mathrm{CH}_{4}, 5 . / \mathrm{d} 10 \% \mathrm{H}_{2}$ and rest $\mathrm{N}_{2}$, Multax, Zielonki-Parcela, Poland) using PeakSimple ver. 3.29 (Szumacher-Strabel et al., 2011). In experiment 2, methane generation during microbial fermentation was estimated based on theoretical stoichiometry of ruminal molar proportions of individual VFA and OM degraded in the rumen (Wolin, 1960). Methane production in experiment 3 was continuously measured by infrared methane analyzers (Servomex 4000 Series, Servomex Ltd., Jarvis Brook, UK) and employing 1,210 Gfx modules using the gas filter correlation technique during 
the feeding of concentrate in the feeder station. Two infrared methane analyzers were used with a range of 0 to $500 \mathrm{ppm}\left(0-625 \mathrm{mg} / \mathrm{m}^{3}\right)$ for ambient air and 0 to $1,000 \mathrm{ppm}\left(0-1,250 \mathrm{mg} / \mathrm{m}^{3}\right)$ for feeding station where concentrates were supplied. Air samples were continuously collected from the feed bins in the feeder stations at $15 \mathrm{~L} / \mathrm{min}$ via an $8-\mathrm{mm}$ diameter polyethylene tube approximately $25 \mathrm{~m}$ in length and connected to a gas panel. The gas samples were distributed to the inlet port of the analyzer with a flow rate of $0.6 \mathrm{~L} / \mathrm{min}$. To decrease the system response time, an additional gas sample was driven by a by-pass line. An external pump was used to draw air between the gas inlet to the sample panel and the outlet of the feeding station. Methane concentrations were measured at 2-s intervals and data were stored on a computer using software with a database system (RS 232; AnaGaz, Wroclaw, Poland). Before measurement of methane concentrations in gas samples, the analyzers were calibrated using a standard calibration gas (Multax, ZielonkiParcela, Poland) containing 1,210 ppm of methane in nitrogen gas (99.99\%).

Fatty Acid Analysis. The FA concentrations in samples were determined using a gas chromatograph (Szczechowiak et al., 2016). Briefly, $3 \mathrm{~mL}$ of $2 \mathrm{M} \mathrm{NaOH}$ solution was added to $2,500,100$, and $500 \mathrm{mg}$ of ruminal fluid, feed, and milk samples, respectively, in screw-cap Teflon-stoppered tubes (glass, $15 \mathrm{~mL}$ ) for hydrolysis of fats. Hydrolyzed FA samples were incubated on a block heater at $90^{\circ} \mathrm{C}$ for $40 \mathrm{~min}$. Samples were then extracted and trans-esterified using $0.5 \mathrm{M} \mathrm{NaOH}$ in methanol borontrifluoride (Fluka, Sigma-Aldrich) to FAME. Analysis of FAME was performed on a gas chromatograph (GC Bruker 456-GC, Billerica, MA) equipped with a capillary column (100-m fused-silica, $0.25 \mathrm{~mm}$ i.d., 0.25 $\mu \mathrm{m}$ film thickness; Chrompack CP7420, Agilent HP) and a flame ionization detector using $1 \mu \mathrm{L}$ of sample injected into the column. Temperatures in injector and detector were maintained at 200 and $250^{\circ} \mathrm{C}$, respectively. The oven temperature was initially set at $120^{\circ} \mathrm{C}$ for $7 \mathrm{~min}$, then increased at a rate of $7^{\circ} \mathrm{C} / \mathrm{min}$ to $140^{\circ} \mathrm{C}$, held for $10 \mathrm{~min}$, and then increased at a rate of $4^{\circ} \mathrm{C} /$ min to $240^{\circ} \mathrm{C}$. Hydrogen gas was used as a carrier gas at a flow rate of $1.3 \mathrm{~mL} / \mathrm{min}$. Fatty acids were identified and quantified with appropriate FAME standards (37 FAME Mix, Sigma-Aldrich). The concentrations of CLA were determined using a CLA standard (a mixture of cis- and trans 9,11 and 10,12-octadecadienoic acid methyl esters; Sigma-Aldrich) using a Galaxie Work Station 10.1 (Varian, CA).

The desaturase indices (Brogna et al., 2011), atherogenic index (Chilliard et al., 2003), thrombogenic index (Ulbricht and Southgate, 1991), and milk energy
(Tyrrell and Reid, 1965) values were estimated using the appropriate equations.

Analysis of Chemical Composition of Milk. Composite milk samples were analyzed for basic milk constituents using an infrared analyzer (Milko-Scan 255 A/S N; Foss Electric, Hillerød, Denmark). Urea concentration in milk was determined in an accredited milk quality laboratory by means of infrared spectrometry using a CombiFoss 6000 analyzer (Foss Electric).

\section{Feed Cost Calculation}

The FeedExpert (Rovecom, Hoogeveen, the Netherlands) software was used to calculate feeding costs of daily cows. The cost was calculated based on the actual prices paid during the duration of the in vivo experiment. It was assumed that the cost of $1 \mathrm{~kg}$ of concentrate feed was approximately $€ 0.21$, whereas the cost of $\mathrm{BC}$ residue was $€ 0.02 / \mathrm{kg}$.

\section{Statistical Analysis}

In experiment 1 , data were obtained only at one time point ( 8 or 24 or $48 \mathrm{~h}$ after start of the in vitro culture) for each replicate. Data within each time point were analyzed in one-way ANOVA with treatment or time as a main factor. Statistical analyses were conducted with Sigma Plot version 11.0. In experiment 2, ruminal fermentation data were analyzed using PROC GLM univariate ANOVA (ver. 9.4, SAS Institute Inc., Cary, NC) for a crossover design with a model containing group (dietary treatment sequence), period, and treatment as main effects, time as repeated measures, and cow as a random effect. The model for the FA analysis contained group, period, and treatment as a main effect. In experiment 3, data were analyzed with the model containing treatment, group, period as fixed effects and cows within a group as a random effect. Statistical analyses for the in vivo experiments were performed using JMP software (SAS Institute Inc.). All pairwise multiple comparisons were performed using a Holm-Sidak test. The results were considered significant when $P<0.05$. All values are shown as the means with pooled standard errors of means.

\section{RESULTS}

\section{Basic Nutrient, Fatty Acid, Phytochemical Contents in Berry Residues, and Cost of Diets}

The BC seed residues contained 262, 58, and 287 $\mathrm{g} / \mathrm{kg}$ of $\mathrm{DM}$ of $\mathrm{CP}, \mathrm{EE}$, and nitrogen-free extract, respectively (Table 2 ). The $\mathrm{SB}$ and $\mathrm{RB}$ seed residues 
Table 2. Chemical composition of the berry seed residues ${ }^{1}$

\begin{tabular}{|c|c|c|c|}
\hline \multirow[b]{2}{*}{ Item } & \multicolumn{3}{|c|}{ Seed residue } \\
\hline & SB & $\mathrm{BC}$ & $\mathrm{RB}$ \\
\hline \multicolumn{4}{|c|}{ Chemical composition, $\mathrm{g} / \mathrm{kg}$ of DM } \\
\hline $\mathrm{OM}$ & 926 & 911 & 949 \\
\hline Ash & 74.1 & 89.4 & 51.1 \\
\hline $\mathrm{CP}$ & 167 & 262 & 110 \\
\hline $\mathrm{CF}$ & 526 & 304 & 585 \\
\hline $\mathrm{EE}$ & 33.8 & 57.9 & 36.3 \\
\hline NFE & 199 & 287 & 218 \\
\hline \multicolumn{4}{|c|}{ Fatty acids (FA), g/100 g of FA } \\
\hline C14:0 & 0.17 & 0.13 & 0.16 \\
\hline $\mathrm{C} 16: 0$ & 6.99 & 7.75 & 4.77 \\
\hline C16:1 & 0.29 & 0.11 & 0.33 \\
\hline $\mathrm{C} 18: 0$ & 2.33 & 2.09 & 1.42 \\
\hline $\mathrm{C} 18: 1$ cis-9 & 15.5 & 11.3 & 9.74 \\
\hline C18:2n-6 & 46.4 & 45.9 & 48.1 \\
\hline C18:3n-3 & 25.8 & 14.6 & 33.1 \\
\hline C18:3n-6 & 0.01 & 12.6 & 0.11 \\
\hline C20:5n-3 & 0.26 & 0.15 & 0.30 \\
\hline SFA & 9.94 & 12.9 & 6.81 \\
\hline UFA & 90.1 & 87.1 & 93.2 \\
\hline MUFA & 17.5 & 13.8 & 11.5 \\
\hline PUFA & 72.6 & 73.3 & 81.7 \\
\hline \multicolumn{4}{|c|}{ Tannins, flavonoids, and anthocyanins, $\mathrm{mg} / 100 \mathrm{~g}$} \\
\hline Tannins $^{2}$ & 87.9 & 2.54 & 150 \\
\hline Flavonoids ${ }^{3}$ & 317 & 18.3 & 240 \\
\hline Anthocyanins & ND & 37.6 & ND \\
\hline
\end{tabular}

contained high amounts of crude fiber (526 and $585 \mathrm{~g} /$ $\mathrm{kg}$ of DM, respectively). The EE in seed residues were mainly of UFA type $(90.1,87.1$, and $93.2 \mathrm{~g} / 100 \mathrm{~g}$ of $\mathrm{FA}$ in $\mathrm{SB}, \mathrm{BC}$, and $\mathrm{RB}$ seed residues, respectively). Linoleic and linolenic acids were the major FA among the UFA. Total MUFA, which mainly consisted of oleic acid, ranged from 11.5, through 13.8 to $17.5 \mathrm{~g} / 100 \mathrm{~g}$ of FA in SB, BC, and RB, respectively. Flavonoid concentrations in $\mathrm{SB}$ seed residues were high, whereas $\mathrm{RB}$ seed residue was rich in both flavonoids and tannins. The BC contained anthocyanins that were not detected in $\mathrm{SB}$ and RB samples.

The daily cost of feed was lower in the BC group compared with the control ( $€ 2.22$ vs. $€ 2.70$ per day, respectively).

\section{In Vitro Experiment}

In experiment 1 , changes in all variables were timedependent and the effects were not always permanent (Table 3). Significant differences in holotrich number, $\mathrm{pH}$ values, and ammonia concentration were observed after the first $8 \mathrm{~h}$ of incubation. The entodiniomorph population and hydrogen recovery were not altered at $8 \mathrm{~h}$ of incubation. Greater ammonia concentration was observed at $8 \mathrm{~h}$ of incubation in RB treatment compared with the control (Table 3). Significant changes in ammonia were also found after $24 \mathrm{~h}$ of incubation. The changes in entodiniomorph counts occurred at $24 \mathrm{~h}$ of incubation in $\mathrm{BC}$ and $\mathrm{RB}$ groups. The rise in hydrogen recovery occurred in the group supplemented with the $\mathrm{RB}$ seed residue compared with the control at $48 \mathrm{~h}$ of fermentation. Several time-dependent changes in VFA proportions were also noticed (Table 4). The highest concentration of the total VFA was found in the BC group after $48 \mathrm{~h}$ fermentation. This was likely due to the increased concentration of 3 VFA (propionate, butyrate, and isovalerate; Table 4).

\section{In Vivo Experiments}

In experiment 2 , total bacteria, total protozoa, holotrichs, and entodiniomorph counts were unaffected in the BC group compared with the control group (Table $5)$. Ammonia concentration increased $(P<0.05)$ at $6 \mathrm{~h}$ postfeeding in the $\mathrm{BC}$ group compared with the control. Many of the VFA profiles were unaffected by treatments. However, isovalerate concentration at 3-h postfeeding was negatively affected by BC $(P<0.05)$ compared with the control (Table 6 ). Methane produc- 
Table 3. Effects of berry seed residues on microbial counts and some ruminal fermentation characteristics in a batch culture system (experiment 1)

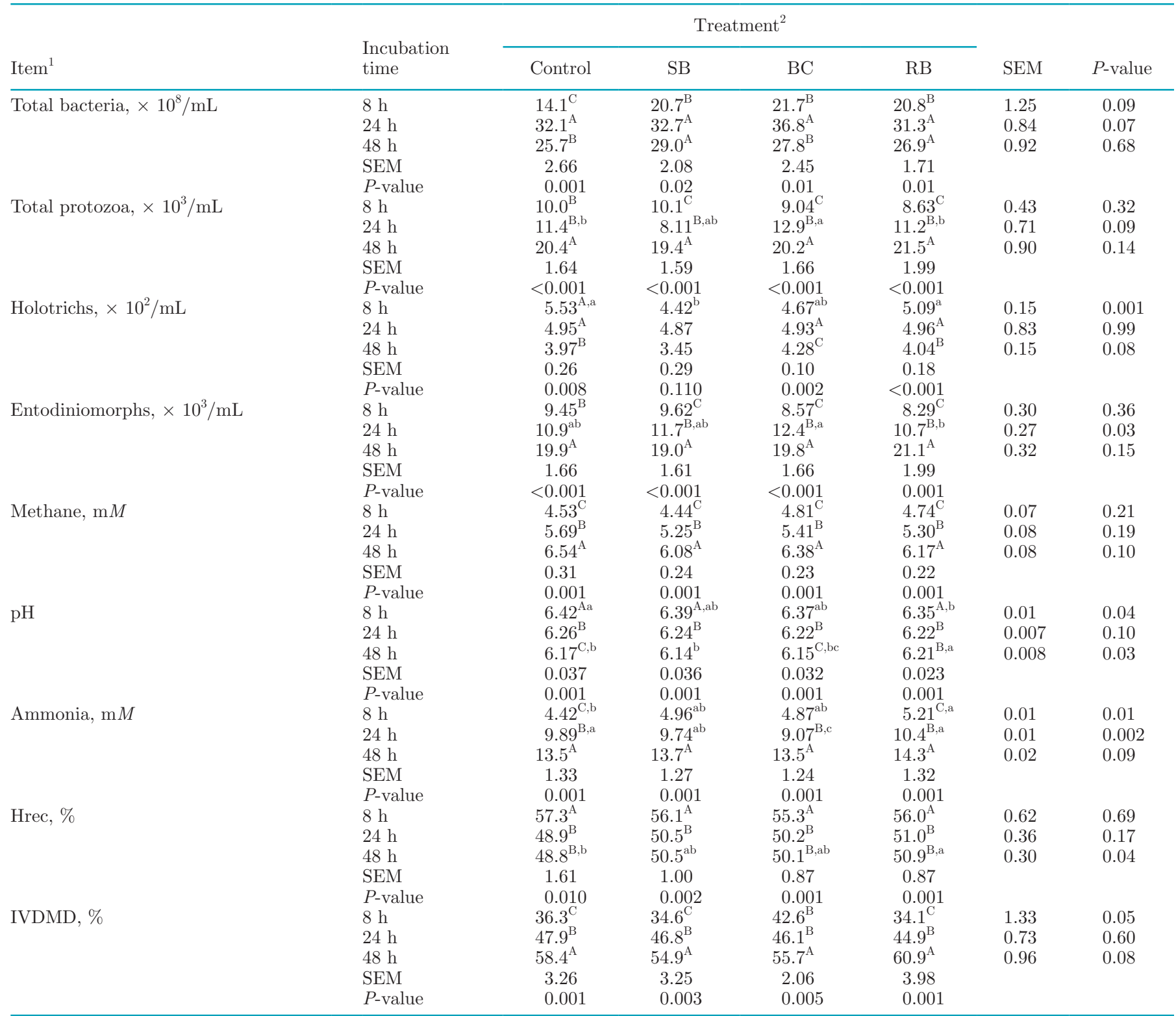

$\overline{\mathrm{A}}^{\mathrm{C}} \mathrm{M}$ Means within a column for a variable with different uppercase superscripts differ $(P<0.05)$.

${ }^{\mathrm{a}-\mathrm{c}}$ Means within a row with different lowercase superscripts differ $(P<0.05)$.

${ }^{1} \mathrm{Hrec}=$ hydrogen recovery; IVDMD $=$ in vitro dry matter digestibility.

${ }^{2} \mathrm{SB}=$ control diet with strawberry seed residues; $\mathrm{BC}=$ control diet with black currant seed residues; $\mathrm{RB}=$ control diet with raspberry seed residues.

tion was time dependent $(P<0.05)$ and was not affected by the $\mathrm{BC}$ feeding. The whole-tract digestibilities of $\mathrm{DM}$ and $\mathrm{CP}$ were unaffected by $\mathrm{BC}$ compared with the control group (Figure 1). As shown in Table 7, BC diet reduced the concentration of $\mathrm{C} 14: 0, \mathrm{C} 15: 0, \mathrm{C} 17: 0$, and C17:1 in ruminal fluid. In contrast, the concentrations of C18:1 trans-11 and C18:2 cis-9,trans-11 significantly increased by 91 and $131 \%$, respectively. Likewise, concentrations of total trans C18:1 and MUFA in ruminal fluid increased in experimental groups. Feeding of BC decreased n-6 FA content in ruminal fluid. Sum of odd(OBCFA) and branched-chain FA (BCFA) concentrations decreased after supplementation of $\mathrm{BC}$ due to their decreased proportions after 3 and $6 \mathrm{~h}$ postfeeding (Table 7). Time of sample collection significantly affected concentration of most FA profiles.

In experiment 3, although milk fat content, milk yield, urea concentration, and methane emission were 
not affected by diets (Table 8), the presence of $\mathrm{BC}$ seed residue altered the FA proportions in milk (Table $9)$. Feeding of BC led to an increased $(P<0.05)$ proportion of the biohydrogenation intermediates; vaccenic acid (C18:1, trans-11; VA), C18:2, cis-9,trans-11 and trans-10,cis-12 isomers as well as C18:2 FA. Proportion of both C20:4n-6 (arachidonic acid) and C22:6n-3 (docosahexaenoic acid) increased $(P<0.05)$ in $\mathrm{BC}$ compared with the control. Feeding of $\mathrm{BC}$ did not affect SFA proportion, but increased $(P<0.05)$ total PUFA concentrations including both n- 6 and n-3, which consequently resulted in increased $(P<0.05)$ PUFA/SFA ratio compared with the control. Among the desaturases indices, $\mathrm{BC}$ decreased $(P<0.05)$ only
C18:1 desaturase index (Table 10). Thrombogenic and atherogenic indices of milk were not changed by $\mathrm{BC}$ supplementation.

\section{DISCUSSION}

The dynamically developing food industries specializing in the production of fruit and vegetable juices produce large quantities of plant residues, which might adversely affect the environment. Supercritical $\mathrm{CO}_{2}$ extraction of berry seeds produces high-quality oil rich in UFA (Helbig et al., 2008). The high nutrient contents of the by-products make them for proper valorization, bringing both ecological and economic benefits (Helbig

Table 4. Effects of berry seed residues on VFA concentrations in rumen fluid incubated in a batch culture system (experiment 1)

\begin{tabular}{|c|c|c|c|c|c|c|c|}
\hline \multirow[b]{2}{*}{ Item } & \multirow{2}{*}{$\begin{array}{l}\text { Incubation } \\
\text { time }\end{array}$} & \multicolumn{4}{|c|}{ Treatment $^{1}$} & \multirow[b]{2}{*}{ SEM } & \multirow[b]{2}{*}{$P$-value } \\
\hline & & Control & $\mathrm{SB}$ & $\mathrm{BC}$ & $\mathrm{RB}$ & & \\
\hline \multirow[t]{5}{*}{ Total VFA, $\mathrm{m} M$} & $8 \mathrm{~h}$ & $39.0^{\mathrm{C}}$ & $38.2^{\mathrm{C}}$ & 38.6 & $37.6^{\mathrm{C}}$ & 0.26 & 0.64 \\
\hline & $24 \mathrm{~h}$ & $57.5^{\mathrm{B}, \mathrm{a}}$ & $56.2^{\mathrm{B}, \mathrm{b}}$ & $58.6^{\mathrm{a}}$ & $55.7^{\mathrm{B}, \mathrm{a}}$ & 0.04 & 0.002 \\
\hline & $48 \mathrm{~h}$ & $70.1^{\mathrm{A}, \mathrm{b}}$ & $69.2^{\mathrm{ab}}$ & $73.6^{\mathrm{a}}$ & $69.4^{\mathrm{A}, \mathrm{b}}$ & 0.06 & 0.003 \\
\hline & SEM & 4.52 & 4.50 & 5.08 & 4.60 & & \\
\hline & $P$-value & 0.001 & 0.001 & 0.001 & 0.001 & & \\
\hline \multirow{5}{*}{ Acetate (A), mM } & $8 \mathrm{~h}$ & $26.2^{\mathrm{C}, \mathrm{a}}$ & $24.9^{\mathrm{C}, \mathrm{b}}$ & $25.9^{\mathrm{C}, \mathrm{a}}$ & $24.9^{\mathrm{C}, \mathrm{b}}$ & 0.02 & 0.01 \\
\hline & $24 \mathrm{~h}$ & $39.1^{\mathrm{B}, \mathrm{a}}$ & $36.7^{\mathrm{B}, \mathrm{b}}$ & $38.5^{\mathrm{B}, \mathrm{a}}$ & $36.4^{\mathrm{B}, \mathrm{b}}$ & 0.04 & 0.001 \\
\hline & $48 \mathrm{~h}$ & $46.6^{\mathrm{A}, \mathrm{a}}$ & $44.1^{\mathrm{A}, \mathrm{b}}$ & $46.9^{\mathrm{A}, \mathrm{a}}$ & $43.9^{\mathrm{A}, \mathrm{b}}$ & 0.04 & 0.001 \\
\hline & SEM & 2.98 & 2.81 & 3.06 & 2.75 & & \\
\hline & $P$-value & 0.001 & 0.001 & 0.001 & 0.001 & & \\
\hline \multirow[t]{5}{*}{ Propionate $(\mathrm{P}), \mathrm{m} M$} & $8 \mathrm{~h}$ & $6.78^{\mathrm{C}}$ & $7.29^{\mathrm{C}}$ & $6.66^{\mathrm{C}}$ & $6.61^{\mathrm{B}}$ & 0.159 & 0.43 \\
\hline & $24 \mathrm{~h}$ & $8.28^{\mathrm{B}, \mathrm{c}}$ & $9.30^{\mathrm{ab}}$ & $9.67^{\mathrm{Ba}}$ & $9.25^{\mathrm{A}, \mathrm{b}}$ & 0.015 & 0.001 \\
\hline & $48 \mathrm{~h}$ & $10.4^{\mathrm{A}, \mathrm{b}}$ & $11.6^{\mathrm{b}}$ & $12.3^{\mathrm{A}, \mathrm{a}}$ & $11.6^{\mathrm{A}, \mathrm{a}}$ & 0.020 & 0.005 \\
\hline & SEM & 0.54 & 0.65 & 0.81 & 0.44 & & \\
\hline & $P$-value & 0.001 & 0.001 & 0.001 & 0.001 & & \\
\hline \multirow[t]{5}{*}{ Butyrate, $\mathrm{m} M$} & $8 \mathrm{~h}$ & $4.87^{\mathrm{C}}$ & $4.91^{\mathrm{C}}$ & $4.90^{\mathrm{C}}$ & $4.95^{\mathrm{C}}$ & 0.028 & 0.83 \\
\hline & $24 \mathrm{~h}$ & $7.94^{\mathrm{B}}$ & $8.02^{\mathrm{B}}$ & $8.12^{\mathrm{B}}$ & $7.87^{\mathrm{B}}$ & 0.053 & 0.44 \\
\hline & $48 \mathrm{~h}$ & $10.0^{\mathrm{A}, \mathrm{b}}$ & $10.2^{\mathrm{A}, \mathrm{b}}$ & $10.9 \mathrm{~A}^{\mathrm{a}}$ & $10.5^{\mathrm{A}, \mathrm{ab}}$ & 0.02 & 0.01 \\
\hline & SEM & 0.75 & 0.76 & 0.87 & 0.81 & & \\
\hline & $P$-value & 0.001 & 0.001 & 0.001 & 0.001 & & \\
\hline \multirow[t]{5}{*}{ Isobutyrate, $\mathrm{m} M$} & $8 \mathrm{~h}$ & $0.35^{\mathrm{C}, \mathrm{b}}$ & $0.33^{\mathrm{C}, \mathrm{b}}$ & $0.33^{\mathrm{C}, \mathrm{b}}$ & $0.37^{\mathrm{C}, \mathrm{a}}$ & 0.005 & 0.04 \\
\hline & $24 \mathrm{~h}$ & $0.47^{\mathrm{B}}$ & $0.46^{\mathrm{B}}$ & $0.48^{\mathrm{B}}$ & $0.46^{\mathrm{B}}$ & 0.004 & 0.57 \\
\hline & $48 \mathrm{~h}$ & $0.63^{\mathrm{A}}$ & $0.68^{\mathrm{A}}$ & $0.70^{\mathrm{A}}$ & $0.66^{\mathrm{A}}$ & 0.013 & 0.24 \\
\hline & SEM & 0.042 & 0.051 & 0.055 & 0.043 & & \\
\hline & $P$-value & 0.001 & 0.001 & 0.001 & 0.001 & & \\
\hline \multirow[t]{5}{*}{ Isovalerate, $\mathrm{m} M$} & $8 \mathrm{~h}$ & $0.44^{\mathrm{C}}$ & $0.44^{\mathrm{C}}$ & $0.46^{\mathrm{C}}$ & $0.44^{\mathrm{C}}$ & 0.008 & 0.09 \\
\hline & $24 \mathrm{~h}$ & $0.73^{\mathrm{B}}$ & $0.74^{\mathrm{B}}$ & $0.78^{\mathrm{B}}$ & $0.74^{\mathrm{B}}$ & 0.010 & 0.42 \\
\hline & $48 \mathrm{~h}$ & $1.23^{\mathrm{A}, \mathrm{b}}$ & $1.40^{\mathrm{A}, \mathrm{a}}$ & $1.49^{\mathrm{A}, \mathrm{a}}$ & $1.40^{\mathrm{ab}}$ & 0.017 & 0.009 \\
\hline & SEM & 0.115 & 0.143 & 0.153 & 0.143 & & \\
\hline & $P$-value & 0.001 & 0.001 & 0.001 & 0.001 & & \\
\hline \multirow{5}{*}{ Valerate, $\mathrm{m} M$} & $8 \mathrm{~h}$ & $0.36^{\mathrm{C}, \mathrm{a}}$ & $0.36^{\mathrm{C}, \mathrm{a}}$ & $0.34^{\mathrm{C}, \mathrm{a}}$ & $0.30^{\mathrm{C}, \mathrm{b}}$ & 0.003 & 0.003 \\
\hline & $24 \mathrm{~h}$ & $1.02^{\mathrm{B}}$ & $0.96^{\mathrm{B}}$ & $1.03^{\mathrm{B}}$ & $0.99^{\mathrm{B}}$ & 0.014 & 0.35 \\
\hline & $48 \mathrm{~h}$ & $1.21^{\mathrm{A}}$ & $1.25^{\mathrm{A}}$ & $1.31^{\mathrm{A}}$ & $1.24^{\mathrm{A}}$ & 0.033 & 0.22 \\
\hline & SEM & 0.111 & 0.132 & 0.144 & 0.140 & & \\
\hline & $P$-value & 0.001 & 0.001 & 0.001 & 0.001 & & \\
\hline \multirow[t]{5}{*}{$\mathrm{A} / \mathrm{P}$ ratio } & $8 \mathrm{~h}$ & $3.87^{\mathrm{B}}$ & $3.90^{\mathrm{B}}$ & 3.89 & $3.89^{\mathrm{B}}$ & 0.011 & 0.86 \\
\hline & $24 \mathrm{~h}$ & $4.01^{\mathrm{A}}$ & $4.03^{\mathrm{A}}$ & 3.98 & $4.05^{\mathrm{A}}$ & 0.015 & 0.41 \\
\hline & $48 \mathrm{~h}$ & $3.95^{\mathrm{AB}}$ & $3.93^{\mathrm{B}}$ & 3.84 & $3.94^{\mathrm{B}}$ & 0.02 & 0.11 \\
\hline & SEM & 0.02 & 0.02 & 0.03 & 0.03 & & \\
\hline & $P$-value & 0.03 & 0.02 & 0.09 & 0.01 & & \\
\hline
\end{tabular}

$\overline{\mathrm{A}-\mathrm{C}}$ Means within a column for a variable with different uppercase superscripts differ $(P<0.05)$.

${ }^{\mathrm{a}-\mathrm{c}}$ Different lowercase superscripts in a row show differences $(P<0.05)$ among treatments.

${ }^{1} \mathrm{SB}=$ control diet with strawberry seed residues; $\mathrm{BC}=$ control diet with black currant seed residues; RB $=$ control diet with raspberry seed residues. 
et al., 2008: Chedea et al., 2017). One of the methods allowing reuse of residues is their application in animal feed industries. However, most of the fruit industry by-products are either composited or combusted, with only a small amounts used in animal diets. The oil and residues contain nonnutritive phytochemicals that can be used to modulate the fermentation process (MirzaeiAghsaghali and Maheri-Sis, 2008; Cieślak et al., 2013). The oils are mainly use in pharmaceutical industry. The main phytochemicals in beery seed residues are tannins and flavonoids. Because of their antimicrobial properties, they have been shown to lower ruminal methane production in vitro and in vivo (Bodas et al., 2009; Patra and Saxena, 2010). The amount of energy lost as methane in ruminant animals may account for 6 to $12 \%$ of gross energy intake, or 8 to $14 \%$ of digestible energy intake (Czerkawski, 1969; Johnson and Ward, 1996). For mitigation of methane production in ruminants, it is crucial to develop a strategy that decreases methane-producing microbial activities and proliferation without limiting beneficial rumen function (Foiklang et al., 2016; Patra, 2016). Berry seed residues were considered as potential factors for modulating rumen microflora populations responsible for methanogenesis. However, each type of phytochemicals such as saponins, tannins, and essential oils has a different effect on rumen microbial populations and methane production (Szumacher-Strabel and Cieslak, 2010; Wencelová et al., 2015, 2016). These effects are generally multifaceted, affecting microorganisms participating in the production of hydrogen as well as utilizing hydrogen to produce methane. We did not confirm the hypothesis that berry seed residues, in the amount used, have strong potential to mitigate rumen methane production; however, methane produced with berry seed residues in in vitro and in vivo studies was numerically lower than the controls.

In the present study, berry seed residues did not generally show antimicrobial activity; however, BC residues modified in vitro ruminal VFA profile. A meta-analysis studying the effects of phytochemicals on ruminal fermentation characteristics concluded that for tannins, for example, a decrease in methane emission is not always related to changes in acetate and propionate concentrations, although acetate to propionate ratio decreased quadratically with inhibition of methane (Patra, 2010). Studies investigating the influence of berry seed by-products on ruminal fermentation are scarce; however, information is available on the effect of various other plant materials containing bioactive compounds on ruminal fermentation, including ciliate protozoal counts. It should be noted that the amount and type of phytofactors have an important influence on modulation of ruminal microbial metabolism (Ohene-Adjei et al., 2008; Wang et al., 2016).

No effects of berry seed residues on methane concentration and acetate-to-propionate ratio were observed. The average concentration of the in vitro total VFA

Table 5. Effect of feeding black currant (BC) seed residues to cannulated dairy cows on basic rumen parameters (experiment 2)

\begin{tabular}{|c|c|c|c|c|c|c|c|}
\hline Item & Treatment & Total & $0 \mathrm{~h}$ & $3 \mathrm{~h}$ & $6 \mathrm{~h}$ & SEM & $P$-value \\
\hline \multirow[t]{4}{*}{ Total bacteria, $\times 10^{8} / \mathrm{mL}$} & Control & 123 & 127 & 115 & 126 & 5.28 & 0.30 \\
\hline & $\mathrm{BC}$ & 126 & 128 & 118 & 132 & 4.50 & 0.08 \\
\hline & SEM & 2.99 & 4.60 & 4.50 & 5.50 & & \\
\hline & $P$-value & 0.44 & 0.83 & 0.65 & 0.44 & & \\
\hline \multirow[t]{4}{*}{ Total protozoa, $\times 10^{4} / \mathrm{mL}$} & Control & 69.5 & 69.2 & 73.9 & 65.4 & 0.565 & 0.35 \\
\hline & $\mathrm{BC}$ & 68.5 & 61.2 & 71.2 & 73.2 & 0.899 & 0.89 \\
\hline & SEM & 0.43 & 0.93 & 0.52 & 0.76 & & \\
\hline & $P$-value & 0.89 & 0.54 & 0.73 & 0.30 & & \\
\hline \multirow[t]{4}{*}{ Holotrichs, $\times 10^{4} / \mathrm{mL}$} & Control & 1.02 & $0.82^{\mathrm{b}}$ & $1.52^{\mathrm{a}}$ & $0.73^{\mathrm{b}}$ & 0.152 & 0.04 \\
\hline & $\mathrm{BC}$ & $0.84^{\mathrm{b}}$ & $0.63^{\mathrm{b}}$ & $1.14^{\mathrm{a}}$ & $0.76^{\mathrm{b}}$ & 0.181 & 0.001 \\
\hline & SEM & 0.09 & 0.09 & 0.22 & 0.11 & & \\
\hline & $P$-value & 0.27 & 0.21 & 0.18 & 0.82 & & \\
\hline \multirow[t]{4}{*}{ Entodiniomorphs, $\times 10^{5} / \mathrm{mL}$} & Control & 6.84 & 6.83 & 7.24 & 6.46 & 0.563 & 0.37 \\
\hline & $\mathrm{BC}$ & 6.77 & 6.05 & 7.01 & 7.25 & 0.899 & 0.92 \\
\hline & SEM & 0.43 & 0.94 & 0.53 & 0.76 & & \\
\hline & $P$-value & 0.92 & 0.55 & 0.78 & 0.30 & & \\
\hline \multirow[t]{4}{*}{$\mathrm{pH}$} & Control & 6.04 & $6.39^{\mathrm{a}}$ & $5.98^{\mathrm{b}}$ & $5.75^{\mathrm{c}}$ & 0.061 & 0.001 \\
\hline & $\mathrm{BC}$ & 6.04 & $6.33^{\mathrm{a}}$ & $6.08^{\mathrm{b}}$ & $5.71^{c}$ & 0.071 & 0.001 \\
\hline & SEM & 0.04 & 0.04 & 0.03 & 0.04 & & \\
\hline & $P$-value & 0.96 & 0.53 & 0.12 & 0.71 & & \\
\hline \multirow[t]{4}{*}{$\mathrm{NH}_{3}, \mathrm{~m} M$} & Control & $9.07^{\mathrm{A}, \mathrm{b}}$ & $6.71^{c}$ & $13.7^{\mathrm{a}}$ & $6.77^{\mathrm{A}, \mathrm{b}}$ & 1.11 & 0.001 \\
\hline & $\mathrm{BC}$ & $10.3^{\mathrm{B}, \mathrm{a}}$ & $7.39^{\mathrm{c}}$ & $12.9^{\mathrm{a}}$ & $10.7^{\mathrm{B}, \mathrm{c}}$ & 1.07 & 0.001 \\
\hline & SEM & 0.13 & 0.34 & 0.96 & 0.90 & & \\
\hline & $P$-value & 0.02 & 0.15 & 0.21 & 0.04 & & \\
\hline
\end{tabular}

\footnotetext{
$\overline{\mathrm{A}, \mathrm{B}}$ Means in a column within a variable with different uppercase superscripts differ $(P<0.05)$.
}

${ }^{\mathrm{a}-\mathrm{c}}$ Means in a row with different lowercase superscripts differ $(P<0.05)$. 
Table 6. Effects of feeding of black currant (BC) seed residues on VFA concentration in ruminal fluid and methane production in cannulated dairy cows (experiment 2)

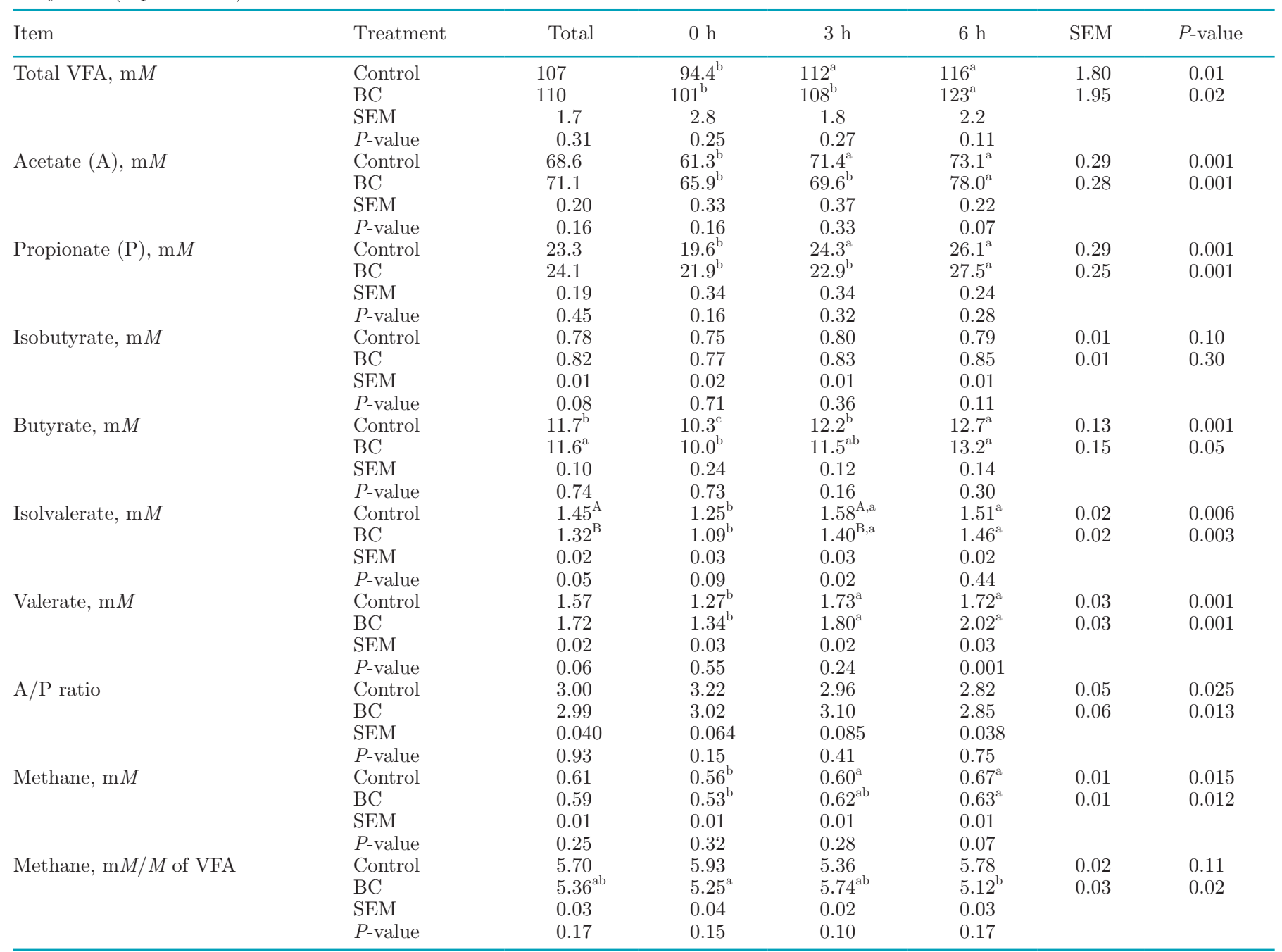

${ }_{\mathrm{A}, \mathrm{B}}$ Means in a column within a variable with different uppercase superscripts differ $(P<0.05)$.

${ }^{\mathrm{a}-\mathrm{c}}$ Means in a row with different lowercase superscripts differ $(P<0.05)$.

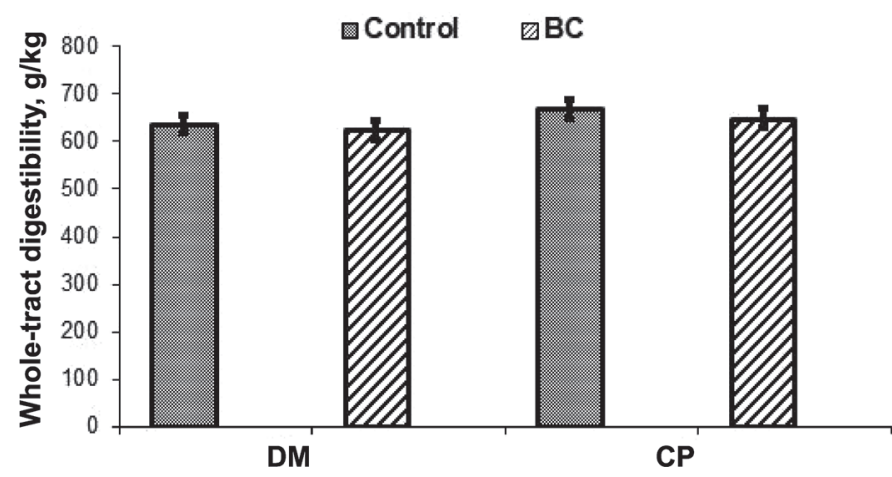

Figure 1. Effect of black currant seed residues on whole-tract digestibility $(\mathrm{g} / \mathrm{kg})$ of $\mathrm{DM}$ and $\mathrm{CP}$ in dairy cows. $\mathrm{BC}=$ control diet with black currant residue. Error bars represent SEM. was higher for the BC diet compared with the control, which was probably as a result of increased concentrations of propionate, butyrate, and isovalerate. Increased VFA concentration, unaltered rumen microbial populations and methane concentration at 24 and 48 $h$ of incubation may suggest that the amount of berry seed by-products used had no negative effects on fermentation in the rumen. This was further confirmed in the in vivo study because no changes were noticed in VFA concentrations, basic rumen parameters, and DM digestibility due to BC supplementation.

In the present experiment, we showed that the berry seed residues could be a significant source of phytofactors. The SB seed residue was a rich source of flavonoids $(317 \mathrm{mg} / 100 \mathrm{~g})$, whereas $\mathrm{RB}$ seed residue was rich in flavonoids and tannins (240 and $150 \mathrm{mg} / 100 \mathrm{~g}$, 
Table 7. Fatty acid (FA) concentration ( $\mathrm{g} / 100 \mathrm{~g}$ of FA) in ruminal fluid of cannulated dairy cows fed a diet with black currant (BC) seed residues (experiment 3 )

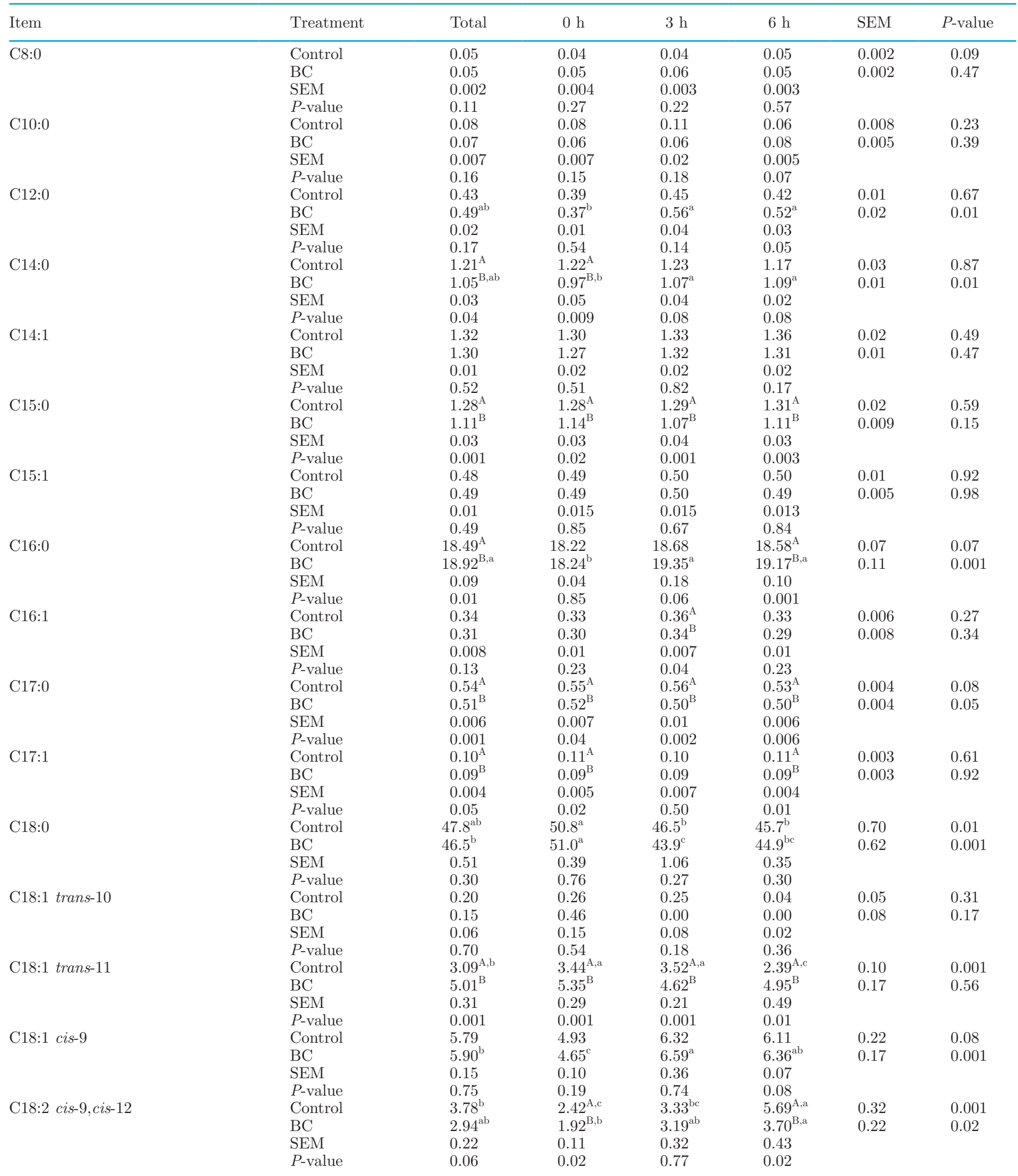


Table 7 (Continued). Fatty acid (FA) concentration (g/100 g of FA) in ruminal fluid of cannulated dairy cows fed a diet with black currant (BC) seed residues (experiment 3)

\begin{tabular}{|c|c|c|c|c|c|c|c|}
\hline Item & Treatment & Total & $0 \mathrm{~h}$ & $3 \mathrm{~h}$ & $6 \mathrm{~h}$ & SEM & $P$-value \\
\hline \multirow{2}{*}{ C18:2 cis-9,trans-11 } & $\mathrm{BC}$ & $1.33^{\mathrm{B}, \mathrm{b}}$ & $0.20^{\mathrm{c}}$ & $2.40^{\mathrm{B}, \mathrm{a}}$ & $1.36^{\mathrm{b}}$ & 0.18 & 0.001 \\
\hline & SEM & 0.12 & 0.04 & 0.35 & 0.16 & & \\
\hline \multirow[t]{3}{*}{ C18:2 trans-10, cis-12 } & Control & $0.57^{\mathrm{ab}}$ & $0.25^{\mathrm{b}}$ & $0.47^{\mathrm{b}}$ & $0.99^{\mathrm{A}, \mathrm{a}}$ & 0.08 & 0.009 \\
\hline & $\mathrm{BC}$ & $0.38^{\mathrm{a}}$ & $0.09^{\mathrm{b}}$ & $0.57^{\mathrm{a}}$ & $0.48^{\mathrm{B}, \mathrm{a}}$ & 0.05 & 0.001 \\
\hline & SEM & 0.06 & 0.04 & 0.12 & 0.09 & & \\
\hline \multirow{3}{*}{ C18:3n-6 } & $\mathrm{BC}$ & $0.192^{\mathrm{B}, \mathrm{a}}$ & $0.165^{\mathrm{b}}$ & $0.208^{\mathrm{B}, \mathrm{a}}$ & $0.205^{\mathrm{a}}$ & 0.005 & 0.001 \\
\hline & SEM & 0.004 & 0.004 & 0.006 & 0.007 & & \\
\hline & $P$-value & 0.01 & 0.48 & 0.01 & 0.20 & & \\
\hline \multirow{4}{*}{ C18:3 cis- 9, cis- 12, cis- 15} & Control & 0.68 & 0.60 & 0.85 & 0.60 & 0.06 & 0.52 \\
\hline & $\mathrm{BC}$ & 0.51 & 0.49 & 0.49 & 0.55 & 0.01 & 0.07 \\
\hline & SEM & 0.05 & 0.04 & 0.12 & 0.02 & & \\
\hline & $P$-value & 0.19 & 0.16 & 0.20 & 0.27 & & \\
\hline \multirow{3}{*}{ C20:5n-3 } & $\mathrm{BC}$ & 0.04 & 0.03 & 0.04 & 0.03 & 0.004 & 0.81 \\
\hline & SEM & 0.004 & 0.005 & 0.007 & 0.005 & & \\
\hline & $P$-value & 0.19 & 0.27 & 0.25 & 0.67 & & \\
\hline \multirow[t]{4}{*}{ C22:6n-3 } & Control & 0.41 & 0.40 & 0.40 & 0.44 & 0.01 & 0.58 \\
\hline & $\mathrm{BC}$ & 0.41 & 0.42 & 0.40 & 0.41 & 0.01 & 0.97 \\
\hline & SEM & 0.02 & 0.01 & 0.02 & 0.02 & & \\
\hline & $P$-value & 0.94 & 0.49 & 0.93 & 0.48 & & \\
\hline \multirow[t]{4}{*}{ Sum of other $\mathrm{FA}^{1}$} & Control & 12.7 & 12.5 & 13.2 & 12.4 & 0.16 & 0.26 \\
\hline & $\mathrm{BC}$ & 12.3 & 11.7 & 12.7 & 12.4 & 0.18 & 0.24 \\
\hline & SEM & 0.17 & 0.23 & 0.19 & 0.29 & & \\
\hline & $P$-value & 0.21 & 0.09 & 0.18 & 0.92 & & \\
\hline \multirow[t]{3}{*}{ Sum of SFA } & Control & $72.5^{\mathrm{ab}}$ & $74.9^{\mathrm{a}}$ & $71.5^{\mathrm{b}}$ & $70.7^{\mathrm{b}}$ & 0.54 & 0.008 \\
\hline & $\mathrm{BC}$ & $71.5^{\mathrm{b}}$ & $74.8^{\mathrm{a}}$ & $69.9^{\mathrm{c}}$ & $70.2^{\mathrm{bc}}$ & 0.46 & 0.001 \\
\hline & SEM & 0.38 & 0.31 & 0.79 & 0.21 & & \\
\hline \multirow{4}{*}{ Sum of PUFA } & Control & $7.97^{\mathrm{b}}$ & $5.55^{\mathrm{A}, \mathrm{c}}$ & $7.35^{\mathrm{bc}}$ & $11.23^{\mathrm{A}, \mathrm{a}}$ & 0.54 & 0.001 \\
\hline & $\mathrm{BC}$ & $7.46^{\mathrm{a}}$ & $4.67^{\mathrm{B}, \mathrm{b}}$ & $9.14^{\mathrm{a}}$ & $8.49^{\mathrm{B}, \mathrm{a}}$ & 0.42 & 0.001 \\
\hline & SEM & 0.28 & 0.20 & 0.57 & 0.58 & & \\
\hline & $P$-value & 0.43 & 0.04 & 0.16 & 0.02 & & \\
\hline \multirow[t]{4}{*}{ Sum of n- 6 FA } & Control & $8.94^{\mathrm{A}, \mathrm{b}}$ & $6.15^{\mathrm{A}, \mathrm{b}}$ & $7.99^{\mathrm{b}}$ & $12.87^{\mathrm{A}, \mathrm{a}}$ & 0.65 & 0.001 \\
\hline & $\mathrm{BC}$ & $7.18^{\mathrm{B}, \mathrm{ab}}$ & $4.97^{\mathrm{B}, \mathrm{b}}$ & $7.62^{\mathrm{ab}}$ & $8.75^{\mathrm{B}, \mathrm{a}}$ & 0.44 & 0.009 \\
\hline & SEM & 0.46 & 0.23 & 0.63 & 0.87 & & \\
\hline & $P$-value & 0.05 & 0.01 & 0.79 & 0.02 & & \\
\hline Sum of n-3 FA & Control & 1.59 & 1.48 & 1.75 & 1.58 & 0.06 & 0.54 \\
\hline & $\mathrm{BC}$ & 1.46 & 1.43 & 1.48 & 1.49 & 0.02 & 0.85 \\
\hline & SEM & 0.06 & 0.04 & 0.12 & 0.04 & & \\
\hline & $P$-value & 0.35 & 0.58 & 0.29 & 0.31 & & \\
\hline Sum of trans C18:1 & Control & $6.55^{\mathrm{A}, \mathrm{b}}$ & $7.36^{\mathrm{A}, \mathrm{a}}$ & $7.28^{\mathrm{ab}}$ & $4.96^{\mathrm{A}, \mathrm{c}}$ & 0.23 & 0.001 \\
\hline & $\mathrm{BC}$ & $7.99^{\mathrm{B}}$ & $8.79^{\mathrm{B}}$ & 7.22 & $7.87^{\mathrm{B}}$ & 0.24 & 0.18 \\
\hline & SEM & 0.24 & 0.28 & 0.17 & 0.58 & & \\
\hline & $P$-value & 0.001 & 0.004 & 0.88 & 0.01 & & \\
\hline Sum of medium-chain FA & Control & 26.8 & 26.2 & 27.4 & 27.0 & 0.21 & 0.14 \\
\hline & $\mathrm{BC}$ & $26.9^{\mathrm{a}}$ & $25.7^{\mathrm{b}}$ & $27.9^{\mathrm{a}}$ & $27.2^{\mathrm{a}}$ & 0.21 & 0.001 \\
\hline & SEM & 0.18 & 0.20 & 0.33 & 0.19 & & \\
\hline & $P$-value & 0.72 & 0.27 & 0.47 & 0.73 & & \\
\hline
\end{tabular}


Table 7 (Continued). Fatty acid (FA) concentration (g/100 g of FA) in ruminal fluid of cannulated dairy cows fed a diet with black currant (BC) seed residues (experiment 3)

\begin{tabular}{|c|c|c|c|c|c|c|c|}
\hline Item & Treatment & Total & $0 \mathrm{~h}$ & $3 \mathrm{~h}$ & $6 \mathrm{~h}$ & SEM & $P$-value \\
\hline \multirow{2}{*}{ Sum of long-chain FA } & $\mathrm{BC}$ & $72.7^{\mathrm{b}}$ & $74.0^{\mathrm{a}}$ & $71.6^{\mathrm{b}}$ & $72.4^{\mathrm{b}}$ & 0.22 & 0.001 \\
\hline & SEM & 0.19 & 0.21 & 0.35 & 0.18 & & \\
\hline \multirow[t]{3}{*}{ Sum of $\mathrm{BCFA}^{2}$} & Control & $1.15^{\mathrm{A}}$ & 1.07 & $1.26^{\mathrm{A}}$ & $1.10^{\mathrm{A}}$ & 0.03 & 0.22 \\
\hline & $\mathrm{BC}$ & $1.04^{\mathrm{B}}$ & 1.04 & $1.06^{\mathrm{B}}$ & $1.02^{\mathrm{B}}$ & 0.02 & 0.66 \\
\hline & SEM & 0.03 & 0.04 & 0.05 & 0.04 & & \\
\hline \multirow{3}{*}{ Sum of $\mathrm{OBCFA}^{2}$} & $\mathrm{BC}$ & $2.27^{\mathrm{B}}$ & 2.33 & $2.24^{\mathrm{B}}$ & $2.24^{\mathrm{B}}$ & 0.02 & 0.45 \\
\hline & SEM & 0.04 & 0.05 & 0.05 & 0.04 & & \\
\hline & $P$-value & 0.01 & 0.18 & 0.002 & 0.03 & & \\
\hline \multirow{4}{*}{ PUFA/SFA ratio } & Control & $0.11^{\mathrm{b}}$ & $0.07^{\mathrm{A}, \mathrm{c}}$ & $0.10^{\mathrm{bc}}$ & $0.16^{\mathrm{A}, \mathrm{a}}$ & 0.008 & 0.001 \\
\hline & $\mathrm{BC}$ & $0.11^{\mathrm{a}}$ & $0.06^{\mathrm{B}, \mathrm{b}}$ & $0.13^{\mathrm{a}}$ & $0.12^{\mathrm{B}, \mathrm{a}}$ & 0.006 & 0.001 \\
\hline & SEM & 0.004 & 0.003 & 0.009 & 0.008 & & \\
\hline & $P$-value & 0.55 & 0.05 & 0.17 & 0.02 & & \\
\hline
\end{tabular}

${ }_{\mathrm{A}, \mathrm{B}}$ Means in a column within a variable with different uppercase superscripts differ $(P<0.05)$.

${ }^{\mathrm{a}-\mathrm{c}}$ Means in a row with different lowercase superscripts differ $(P<0.05)$.

${ }^{1}$ Other FA include C6, C10:1, C11:0, C12 iso, C12 anteiso, C13:0, C14 anteiso, C15 anteiso, C16 anteiso, C16 iso, C16:1 trans, C17 iso, C17 anteiso, C18:1 trans-5, C18:1 trans-6-8, C18:1 trans-9. C18:1 trans-15, C18:1 cis-11. C18:1 cis-12, C18:1 cis-13. C18:1 cis-14. C19:0, C18:1 cis15, C18:2 cis-9,cis-12, C18:2 cis-9,cis-15, C20:0, C20:1 trans, C18:3n-6, C21:0, C20:2, C22:0, C20:3n-6, C22:1n-9, C20:3n-3, C23:0, C22:2, C24:0, and $\mathrm{C} 24: 1$.

${ }^{2} \mathrm{BCFA}=$ branched-chain fatty acids; OBCFA = odd and branched-chain fatty acids.

respectively). The lowest content of phytofactors was found in $\mathrm{BC}$ seed residue; however, $\mathrm{BC}$ was a source of anthocyanins (tannins $2.54 \mathrm{mg} / 100 \mathrm{~g}$; flavonoids 18 $\mathrm{mg} / 100 \mathrm{~g}$; and anthocyanins $38 \mathrm{mg} / 100 \mathrm{~g}$ ). Increased VFA concentration and unaltered rumen microbial populations and methane concentration at 24 and 48 $\mathrm{h}$ of incubation may suggest that the amount of berry seed residues used had no negative effects on fermentation in the rumen.
Phytofactors including tannins can reduce the number of protozoa and microorganisms actively influencing rumen fermentations (Makkar et al., 1995; SzumacherStrabel and Cieslak, 2010; Henke et al., 2017). It has been shown that increasing concentrations of condensed tannins from quebracho extract decreased entodiniomorph (0.2 mg of tannins/mL of rumen fluid) and holotrich (0.05 and $0.1 \mathrm{mg}$ of tannins/mL of rumen fluid) populations (Carulla et al., 2005). The in vitro (Carulla

Table 8. Effect of feeding black currant (BC) seed residues to dairy cows on the milk production, yield, and composition

\begin{tabular}{lcccc}
\hline & \multicolumn{2}{c}{ Treatment } & & \\
\cline { 2 - 3 } Item & Control & BC & SEM & $P$-value \\
\hline Milk production, $\mathrm{kg}$ & 30.3 & 29.7 & 0.55 & 0.31 \\
Milk composition & & & & \\
Fat, g/kg & 41.6 & 41.1 & 0.38 & 0.92 \\
CP, g/kg & 35.1 & 34.4 & 0.18 & 0.38 \\
Lactose, g/kg & 51.6 & 50.4 & 0.22 & 0.37 \\
TS, g/kg & 128 & 126 & 1.2 & 0.81 \\
SNF, g/kg & 86.7 & 84.8 & 0.33 & 0.37 \\
Energy, Mcal/kg & 0.75 & 0.74 & 0.004 & 0.87 \\
Methane, $\mu \mathrm{L} / \mathrm{L}$ & 324 & 317 & 3.3 & 0.68 \\
Urea, mg/L & 297 & 294 & 3.3 & 0.86 \\
Yield & & & & \\
Fat, g/d & 1,244 & 1,196 & 19.9 & 0.23 \\
CP, g/d & 1,063 & 1,018 & 18.4 & 0.20 \\
Lactose, g/d & 1,562 & 1,494 & 27.0 & 0.19 \\
Energy, Mcal/d & 22.7 & 21.8 & 0.36 & 0.42 \\
\hline
\end{tabular}


Table 9. Effect of feeding black currant (BC) seed residues to dairy cows on fatty acid (FA) concentrations $(\mathrm{g} / 100 \mathrm{~g}$ of $\mathrm{FA})$ in milk (experiment 3 )

\begin{tabular}{|c|c|c|c|c|}
\hline \multirow[b]{2}{*}{ Item } & \multicolumn{2}{|c|}{ Treatment } & \multirow[b]{2}{*}{ SEM } & \multirow[b]{2}{*}{$P$-value } \\
\hline & Control & $\mathrm{BC}$ & & \\
\hline \multicolumn{5}{|l|}{ SFA } \\
\hline $\mathrm{C} 8: 0$ & 0.99 & 0.91 & 0.020 & 0.16 \\
\hline C10:0 & 2.81 & 2.70 & 0.035 & 0.18 \\
\hline $\mathrm{C} 12: 0$ & 3.69 & 3.55 & 0.037 & 0.10 \\
\hline C14:0 & 11.2 & 11.2 & 0.083 & 0.89 \\
\hline C14:1 & 1.20 & 1.24 & 0.021 & 0.45 \\
\hline C15:0 & 1.31 & 1.32 & 0.012 & 0.77 \\
\hline C15:1 & 0.41 & 0.45 & 0.006 & 0.005 \\
\hline C16:0 & 29.4 & 28.9 & 0.16 & 0.33 \\
\hline C16:1 & 1.78 & 1.64 & 0.033 & 0.10 \\
\hline $\mathrm{C} 17: 0$ & 0.61 & 0.62 & 0.006 & 0.27 \\
\hline $\mathrm{C} 17: 1$ & 0.29 & 0.29 & 0.004 & 1.0 \\
\hline C18:0 & 10.7 & 11.2 & 0.13 & 0.039 \\
\hline \multicolumn{5}{|l|}{ MUFA } \\
\hline $\mathrm{C} 18: 1$ trans -10 & 0.47 & 0.49 & 0.008 & 0.75 \\
\hline C18:1 trans-11 & 1.26 & 1.35 & 0.004 & 0.016 \\
\hline C18:1 cis-9 & 22.5 & 21.9 & 0.79 & 0.54 \\
\hline \multicolumn{5}{|l|}{ PUFA } \\
\hline C18:2 cis-9,cis-12 & 2.21 & 2.28 & 0.579 & 0.39 \\
\hline C18:2 cis-9,trans-11 & 0.71 & 0.78 & 0.001 & 0.002 \\
\hline C18:2 trans -10, cis- 12 & 0.19 & 0.22 & 0.003 & 0.039 \\
\hline C18:3 cis-9,cis-12,cis-15 & 0.44 & 0.49 & 0.019 & 0.020 \\
\hline C20:4n-6 & 0.10 & 0.12 & 0.003 & 0.017 \\
\hline C20:5n-3 & 0.09 & 0.10 & 0.004 & 0.29 \\
\hline $\mathrm{C} 22: 6 \mathrm{n}-3$ & 0.11 & 0.14 & 0.004 & 0.002 \\
\hline Other $\mathrm{FA}^{1}$ & 40.2 & 43.6 & 0.74 & 0.017 \\
\hline \multicolumn{5}{|l|}{ Total FA } \\
\hline Sum of SFA & 64.3 & 64.0 & 0.20 & 0.47 \\
\hline Sum of UFA & 35.7 & 36.0 & 0.19 & 0.85 \\
\hline Sum of MUFA & 31.5 & 31.2 & 0.16 & 0.22 \\
\hline Sum of PUFA & 4.23 & 4.76 & 0.074 & 0.001 \\
\hline Sum of n-6 FA & 2.91 & 3.16 & 0.092 & 0.004 \\
\hline Sum of n-3 FA & 0.74 & 0.90 & 0.024 & 0.003 \\
\hline Sum of trans-C18:1 & 2.39 & 2.66 & 0.029 & 0.001 \\
\hline Sum of medium-chain FA & 50.0 & 49.2 & 0.24 & 0.097 \\
\hline Sum of long-chain FA & 44.9 & 45.9 & 0.26 & 0.060 \\
\hline Sum of BCFA ${ }^{2}$ & 1.82 & 1.82 & 0.015 & 0.91 \\
\hline Sum of $\mathrm{OBCFA}^{2}$ & 3.29 & 3.30 & 0.026 & 0.80 \\
\hline PUFA/SFA ratio & 0.066 & 0.075 & 0.002 & 0.004 \\
\hline n-6/n-3 FA ratio & 4.18 & 3.86 & 0.107 & 0.11 \\
\hline
\end{tabular}

${ }^{1}$ Other FA include C6, C10:1, C11:0, C12 iso, C12 anteiso, C13:0, C14 anteiso, C15 anteiso, C16 anteiso, C16 iso, C16:1 trans, C17 iso, C17 anteiso, C18:1 trans-5, C18:1 trans-6-8, C18:1 trans-9, C18:1 trans-15, C18:1 cis11, C18:1 cis-12, C18:1 cis-13, C18:1 cis-14, C19:0, C18:1 cis-15, C18:2 cis-9,cis-12, C18:2 cis-9, cis-15, C20:0, C20:1 trans, C18:3n-6, C21:0, C20:2, C22:0, C20:3n-6, C22:1n-9, C20:3n-3, C23:0, C22:2, C24:0, and C24:1.

${ }^{2} \mathrm{BCFA}=$ branched-chain fatty acids; OBCFA = odd and branched-chain fatty acids.

et al., 2005) and in vivo (Benchaar and Chouinard, 2009; Szczechowiak et al., 2016) studies suggested that holotrichs may be more sensitive to condensed tannins than entodiniomorphs. Among the berry seed residues, only SB reduced the holotrich populations after $8 \mathrm{~h}$ of fermentation. This may suggest that not only tannins, but also flavonoids can reduce the number or activity of this group of microorganisms. The 3 different bioactive compounds aforementioned showed combined effects in the rumen environment; however, the mode of action for individual compounds could not be clarified from this study. Most of the effects either on rumen microorganisms or VFA were observed only in the in vitro scale. In vivo, the amount of berry seed residues fed $(2 \mathrm{~kg} / \mathrm{d})$ to animals seemed to have a low effect on ruminal fermentation parameters. In the in vivo study (experiment 2 and 3), the $\mathrm{BC}$ diet significantly decreased proportion of OBCFA and BCFA in the rumen. Few rumen bacterial membranes are rich sources of BCFA and OBCFA (Vlaeminck et al., 2006; Alves et al., 2017), which are recommended to reflect changes in the ruminal microbial populations (Vazirigohar et al., 2018). However, none of the treatments affected the number of bacteria at either the in vitro or in vivo level. 
Table 10. Effects of black currant (BC) seed residues on desaturation (DI), thrombogenic, and atherogenic indices of milk of dairy cows

\begin{tabular}{|c|c|c|c|c|}
\hline \multirow[b]{2}{*}{ Item } & \multicolumn{2}{|c|}{ Treatment } & \multirow[b]{2}{*}{ SEM } & \multirow[b]{2}{*}{$P$-value } \\
\hline & Control & $\mathrm{BC}$ & & \\
\hline$\overline{\mathrm{DI}^{1}}$ & 0.32 & 0.32 & 0.002 & 0.46 \\
\hline DI C14: $1^{1}$ & 0.096 & 0.099 & 0.002 & 0.36 \\
\hline DI C16:1 $1^{1}$ & 0.057 & 0.053 & 0.001 & 0.22 \\
\hline DI C18: $1^{1}$ & 0.68 & 0.66 & 0.003 & 0.006 \\
\hline $\mathrm{DI} \mathrm{RA} /(\mathrm{VA}+\mathrm{RA})^{1}$ & 0.37 & 0.37 & 0.003 & 0.85 \\
\hline Thrombogenic index ${ }^{2}$ & 2.48 & 2.40 & 0.024 & 0.22 \\
\hline Atherogenic index ${ }^{3}$ & 2.21 & 2.18 & 0.022 & 0.61 \\
\hline
\end{tabular}

${ }^{1}$ According to Brogna et al. (2011). VA = vaccenic acid; RA = rumenic acid.

${ }^{2}$ According to Ulbricht and Southgate (1991).

${ }^{3}$ According to Chilliard et al. (2003).

Decreased concentrations of BCFA and OBCFA in the rumen were also not reflected in reducing $\mathrm{DM}$ or $\mathrm{CP}$ digestibility. Moreover, the lack of important changes in the rumen fermentation processes was supported by similar milk yield between the groups. Ammonia concentration decreased only at $24 \mathrm{~h}$ of incubation when $\mathrm{BC}$ diet was fed (experiment 1); however, no differences were observed at $48 \mathrm{~h}$ and the ammonia concentrations were within the physiological range.

The berry seed residues used in this study, especially $\mathrm{BC}$, due to the lack of negative effects on ruminal fermentation processes both in vitro and in vivo, can be considered as feed components for ruminants. Related to the in vivo productive performance, no changes were noticed in milk production and composition. However, significant changes were tracked in the ruminal and milk FA profile. Several studies have highlighted different effective supplements (e.g., marine lipids and secondary plant metabolites) that can increase the accumulation of VA through inhibition of the last steps of rumen biohydrogenation (Szczechowiak et al., 2016). The changes in FA profile can be directly related to changes in microbial population involved in biohydrogenation process, which was, in the present study, partly supported by changes in BCFA and OBCFA proportions in the ruminal fluid. In the present study, increased proportion of VA $(+62 \%)$ in the ruminal fluid could partly explain the increased proportion of VA $(+7 \%)$ in milk. This process is of special importance because $\Delta^{9}$ desaturase catalyzes the oxidation of VA in the mammary gland, resulting in production of 70 to $95 \%$ of C18:2 cis-9,trans-11 present in the milk (Ebrahimi et al., 2017). In the present study, C18:2 cis-9,trans-11 significantly increased in milk $(+10 \%$, compared with the control group); however, it was not directly related to the proportion of $\mathrm{C} 18: 2$ cis- 9 ,trans-11 in the rumen fluid $(+133 \%$, compared with the control group). Our study showed that higher proportions of VA and CLA in the rumen were not directly linked to proportions of these FA in milk. One possible reason for this is that FA proportions in the rumen fluid do not fully reflect those in the duodenum, which is the main absorption site for FA (Szczechowiak et al., 2016). The milk FA proportions also depend on the activity of mammary gland desaturases, especially $\Delta^{9}$ desaturase, and genes participating in milk fat synthesis and secretion $(\mathrm{Br}-$ zozowska and Oprządek, 2016; Bernard et al., 2018; Cappucci et al., 2018).

Polyunsaturated FA, including C18:3n-3; C18:3n-6; C20:4n-6, and C22:6n-3, PUFA n-6, and PUFA n-3, significantly increased in milk of cows fed BC-containing diet $(+11,+16,+20,+27,+7$, and $+22 \%$, respectively). Long-chain FA synthesis in the mammary gland indicated a considerable dependence on substrate availability [e.g., C18:0, C18:1 trans-11, C18:3 cis-9, cis12,cis-15 (Urrutia et al., 2015)], which suggested that in the present study, the BC supplement increased inter alia availability of the above FA in the mammary gland. This observation agrees with the results of the experiment by Szczechowiak et al. (2018), in which condensed tannins and fish-soybean oil blend mixture directly modulated the blood n-3 PUFA and finally more n-3 PUFA reached the mammary gland and were secreted in milk. Additionally, it should be also considered that downregulation of the genes involved in longchain PUFA synthesis (e.g., FADS1, FADS2, ELOVL2, and $E L O V 5$ ) by n-3 PUFA in long-term transcriptional regulation could be one of the mechanisms regulating this type of synthesis affecting final FA profile in milk and avoiding excessive levels of these FA (Urrutia et al., 2015).

In the present study, C20:4n-6 and C22:6n-3 significantly increased. The higher proportion of C20:4n-6 and C22:6n-3 in the milk likely resulted from the higher availability of their precursors, C18:2n-6 and C18:3n-6 (Bionaz and Loor, 2008; Cappucci et al., 2018) or from the increase in accessibility of precursors for FA elongation in the liver (Zachut et al., 
2010; Szczechowiak et al., 2018). Therefore, enhancing FA content in milk requires an understanding of the interrelationship among dietary lipid supply, rumen fermentation, and metabolic changes occurring in liver, blood, and finally in mammary gland (Brzozowska and Oprządek, 2016; Varadyova et al., 2018; Szczechowiak et al., 2018). Additionally, the cost associated with the $\mathrm{BC}$ residue supplementation was calculated considering the cost of the individual ingredients of the control and $\mathrm{BC}$ diets. The cost of daily $\mathrm{BC}$ supplemented diet was $\sim 18 \%$ less than the cost of feeding cows the control diet, mainly due to the fact of replacement of $2 \mathrm{~kg} / \mathrm{d}$ per cow concentrate by the same amount of $\mathrm{BC}$ residue.

\section{CONCLUSIONS}

The amount of $\mathrm{BC}$ seed residues used in this study did not affect in vivo ruminal fermentation parameters, methane production or milk production, and basic composition. However, the milk FA profile including increased C18:2 cis-9,trans-11 (CLA), arachidonic acid and docosahexaenoic acid, total PUFA, and n-6 FA and n-3 FA concentration, and PUFA to SFA ratio was better for the BC-supplemented group compared with control. Berry seed residues as an example of waste by-products can be successfully used as dietary components partly replacing more expensive concentrate feeds in dairy cow diets. Incorporation of berry seed residues in diets would be beneficial economically and nutritionally.

\section{ACKNOWLEDGMENTS}

The authors thank the De Heus Company (Leczyca, Poland), particularly W. Szwarc and P. Kasprowicz, for economic consulting. Research was conducted through the statutory funding of the Faculty of Veterinary Medicine and Animal Science Poznan University of Life Sciences, Poland; Department of Animal Nutrition (in vitro study) and National Science Center (Krakow, Poland) 2013/09/B/NZ9/02364 (in vivo study).

\section{REFERENCES}

Alves, S. P., A. Francisco, M. Costa, J. Santos-Silva, and R. J. Bessa. 2017. Biohydrogenation patterns in digestive contents and plasma of lambs fed increasing levels of a tanniferous bush (Cistus ladanifer L.) and vegetable oils. Anim. Feed Sci. Technol. 225:157-172. https://doi.org/10.1016/j.anifeedsci.2017.01.018.

Association of Official Analytical Chemists (AOAC). 2007. Official Methods of Analysis. 18th ed. AOAC International, Gaithersburg, MD.

Balcells, J., A. Aris, A. Serrano, A. R. Seradj, J. Crespo, and M. Devant. 2012. Effects of an extract of plant flavonoids (Bioflavex $\left.{ }^{\circledR}\right)$ on rumen fermentation and performance in heifers fed highconcentrate diets. J. Anim. Sci. 90:4975-4984. https://doi.org/10 $.2527 /$ jas.2011-4955.
Benchaar, C., and P. Y. Chouinard. 2009. Short communication: Assessment of the potential of cinnamaldehyde, condensed tannins, and saponins to modify fatty acid composition of dairy cows. J. Dairy Sci. 92:3392-3396. https://doi.org/10.3168/jds.2009-2111.

Bernard, L., M. Bonnet, C. Delavaud, M. Delosière, A. Ferlay, H. Fougère, and B. Graulet. 2018. Milk fat globule in ruminant: Major and minor compounds, nutritional regulation and differences among species. Eur. J. Lipid Sci. Technol. 120. https://doi.org/10 .1002 ejlt.201700039.

Bionaz, M., and J. J. Loor. 2008. Gene networks driving bovine milk fat synthesis during the lactation cycle. BMC Genomics 9:366-387. https://doi.org/10.1186/1471-2164-9-366.

Bodas, R., S. López, M. Fernandez, R. Garcia-Gonzalez, R. J. Wallace, and J. S. González. 2009. Phytogenic additives to decrease in vitro ruminal methanogenesis. Options Méditerranéennes. 85:279-283.

Brogna, D. M. R., S. Nasri, H. Ben-Salem, M. Mele, A. Serra, M. Bella, A. Priolo, H. P. S. Makkar, and V. Vasta. 2011. Effect of dietary saponins from Quillaja saponaria L. on fatty acid composition and cholesterol content in muscle Longissimus dorsi of lambs. Animal 5:1124-1130. https://doi.org/10.1017/S1751731111000048.

Broudiscou, L. P., Y. Papon, and A. F. Broudiscou. 2002. Effects of dry plant extracts on feed degradation and the production of rumen microbial biomass in a dual outflow fermenter. Anim. Feed Sci. Technol. 101:183-189. https://doi.org/10.1016/S0377 -8401(02)00221-3.

Brzozowska, A. M., and J. Oprządek. 2016. Metabolism of fatty acids in tissues and organs of the ruminants-A review. Anim. Sci. Pap. Rep. 34:211-220.

Buccioni, A., M. Pauselli, C. Viti, S. Minieri, G. Pallara, V. Roscini, S. Rapaccini, M. Trabalza Marinucci, P. Lupi, G. Conte, and M. Mele. 2015. Milk fatty acid composition, rumen microbial population, and animal performances in response to diets rich in linoleic acid supplemented with chestnut or quebracho tannins in dairy ewes. J. Dairy Sci. 98:1145-1156. https://doi.org/10.3168/jds.2014 -8651 .

Cappucci, A. S. P. Alves, R. J. Bessa, A. Buccioni, F. Mannelli, M. Pauselli, C. Viti, R. Pastorelli, V. Roscini, A. Serra, G. Conte, and M. Mele. 2018. Effect of increasing amounts of olive crude phenolic concentrate in the diet of dairy ewes on rumen liquor and milk fatty acid composition. J. Dairy Sci. 101:4992-5005. https://doi .org/10.3168/jds.2017-13757.

Carulla, J. E., M. Kreuzer, A. Machmuller, and H. D. Hess. 2005. Supplementation of Acacia mearnsii tannins decreases methanogenesis and urinary nitrogen in forage-fed sheep. Aust. J. Agric. Res. 91:4765-4777. https://doi.org/10.1071/AR05022.

Chedea, V. S., R. S. Pelmus, C. Lazar, G. Cecilia, L. G. Calin, S. M. Toma, and C. Dragomir. 2017. Effects of a diet containing dried grape pomace on blood metabolites and milk composition of dairy cows. J. Sci. Food Agric. 97:2516-2523. https://doi.org/10.1002/ jsfa. 8068.

Chilliard, Y., A. Ferlay, J. Rouel, and G. Lamberett. 2003. A review of nutritional and physiological factors affecting goat milk lipid synthesis and lipolysis. J. Dairy Sci. 86:1751-1770. https://doi.org/10 .3168/jds.S0022-0302(03)73761-8.

Cieślak, A., Z. Váradyová, S. Kišidayová, D. Jalč, and M. SzumacherStrabel. 2013. Effect of diets with fruit oils supplements on rumen fermentation parameters, fatty acid composition and methane production in vitro. J. Anim. Feed Sci. 22:26-34. https://doi.org/10 $.22358 / \mathrm{jafs} / 66013 / 2013$.

Czerkawski, J. W. 1969. Methane production in ruminants and its significance. World Rev. Nutr. Diet. 11:240-282.

Ebrahimi, M., M. A. Rajion, K. D. Adeyemi, S. Jafari, M. F. Jahromi, E. Oskoueian, G. Y. Meng, and M. H. Ghaffari. 2017. Dietary n -6:n-3 fatty acid ratios alter rumen fermentation parameters and microbial populations in goats. J. Agric. Food Chem. 65:737-744. https://doi.org/10.1021/acs.jafc.6b04704.

FAOSTAT. 2016. Food and agriculture data. Food and Agriculture Organization of the United Nations Statistics Division, Rome, Italy. Accessed Nov. 19, 2018. http://faostat.fao.org/site/291/default .aspx. 
Foiklang, S., M. Wanapat, and T. Norrapoke. 2016. Effect of grape pomace powder, Mangosteen peel powder and monensin on nutrient digestibility, rumen fermentation, nitrogen balance and microbial protein synthesis in dairy steers. Asian-australas. J. Anim. Sci. 29:1416-1423. https://doi.org/10.5713/ajas.15.0689.

Helbig, D., V. Bohm, A. Wagner, R. Schuberta, and G. Jahreis. 2008. Berry seed press residue and their valuable ingredients with special regard to black currant seed press residues. Food Chem. 111:10431049. https://doi.org/10.1016/j.foodchem.2008.05.017.

Henke, A., E. Westreicher-Kristen, J. Molkentin, U. Dickhoefer, K. Knappstein, M. Hasler, and A. Susenbeth. 2017. Effect of dietary quebracho tannin extract on milk fatty acid composition in cows. J. Dairy Sci. 100:6229-6238. https://doi.org/10.3168/jds.2016 -12149 .

Janda, B., A. Stochmal, and W. Oleszek. 2007. The LC-ESI/MS/MS determination of procyanidins in grape seed extracts. Planta Med. 73:908. https://doi.org/10.1055/s-2007-987052.

Johnson, D. E., and G. M. Ward. 1996. Estimates of animal methane emissions. Environ. Monit. Assess. 42:133-141.

Lazze, M. C., R. Pizzala, M. Savio, L. A. Stivala, E. Prosperi, and L. Bianchi. 2003. Anthocyanins protect against DNA damage induced by tert-butyl-hydroperoxide in rat smooth muscle and hepatoma cells. Mutat. Res. 535:103-115. https://doi.org/10.1016/ S1383-5718(02)00285-1.

Makkar, H. P. S., K. Becker, H. J. Abel, and C. Szegletti. 1995. Degradation of condensed tannins by rumen microbes exposed to quebracho tannins (QT) in rumen simulation technique (RUSITEC) and effects of QT on fermentation processes in the RUSITEC. J. Sci. Food Agric. 69:495-500. https://doi.org/10.1016/S1383 $-5718(02) 00285-1$.

Mirzaei-Aghsaghali, A., and N. Maheri-Sis. 2008. Nutritive value of some agro-industrial by-products for ruminants-A review. World J. Zool. 3:40-46.

Ohene-Adjei, S., A. V. Chaves, T. A. McAllister, C. Benchaar, R. M. Teather, and R. J. Forster. 2008. Evidence of increased diversity of methanogenic archaea with plant extract supplementation. Microb. Ecol. 56:234-242. https://doi.org/10.1007/s00248-007-9340 -0 .

Patra, A. K. 2010. Meta-analyses of effects of phytochemicals on digestibility and rumen fermentation characteristics associated with methanogenesis. J. Sci. Food Agric. 90:2700-2708. https://doi .org/10.1002/jsfa.4143.

Patra, A. K. 2016. Recent advances in measurement and dietary mitigation of enteric methane emissions in ruminants. Front. Vet. Sci. 3:39. https://doi.org/10.3389/fvets.2016.00039.

Patra, A. K., and J. Saxena. 2010. A new perspective on the use of plant secondary metabolites to inhibit methanogenesis in the rumen. Phytochemistry 71:1198-1222. https://doi.org/10.1016/j .phytochem.2010.05.010.

Roj, E., A. Dobrzynska-Inger, D. Kostrzewa, K. Kołodziejczyk, M. Sojka, B. Krol, A. Miszczak, and J. Markowski. 2009. Extraction of berry seed oils with supercritical $\mathrm{CO}_{2}$ [In Polish: Otrzymywanie ekstraktów olejowych z nasion owoców jagodowych z wykorzystaniem $\mathrm{CO}_{2}$ w warunkach nadkrytycznych]. Przem. Chem. 88:13251330.

Stochmal, A., and W. Oleszek. 2007. Seasonal and structural changes of flavones in alfalfa (Medicago sativa) aerial parts. J. Food Agric. Environ. 5:170-174.

Szczechowiak, J., K. Szkudelska, M. Szumacher-Strabel, S. Sadkowski, K. Gwozdz, M. El-Sherbiny, M. Kozłowska, and A. Cieslak. 2018. Blood hormones, metabolic parameters and fatty acid proportion in dairy cows fed condensed tannins and oils blend. Ann. Anim. Sci. 18:155-166. https://doi.org/10.1515/aoas-2017-0039.

Szczechowiak, J., M. Szumacher-Strabel, M. El-Sherbiny, E. PersKamczyc, P. Pawlak, and A. Cieslak. 2016. Rumen fermentation, methane concentration and fatty acid proportion in the rumen and milk of dairy cows fed condensed tannin and/or fish-soybean oils blend. Anim. Feed Sci. Technol. 216:93-107. https://doi.org/10 .1016/j.anifeedsci.2016.03.014.

Szumacher-Strabel, M., and A. Cieslak. 2010. Potential of phytofactors to mitigate rumen ammonia and methane production. J. Anim. Feed Sci. 19:319-337. https://doi.org/10.22358/jafs/66296/2010.

Szumacher-Strabel, M., P. Zmora, E. Roj, A. Stochmal, E. Pers-Kamczyc, A. Urbanczyk, W. Oleszek, D. Lechniak, and A. Cieslak. 2011. The potential of the wild dog rose (Rosa canina) to mitigate in vitro rumen methane production. J. Anim. Feed Sci. 20:285-299. https://doi.org/10.22358/jafs/66185/2011.

Tangerman, A., and F. M. Nagengast. 1996. A gas chromatographic analysis of fecal short-chain fatty acids, using the direct injection method. Anal. Biochem. 236:1-8. https://doi.org/10.1006/abio .1996.0123.

Tyrrell, H. F., and J. T. Reid. 1965. Prediction of the energy value of cow's milk. J. Dairy Sci. 48:1215-1223. https://doi.org/10.3168/ jds.S0022-0302(65)88430-2.

Ulbricht, T. L. V., and D. A. T. Southgate. 1991. Coronary heart disease: Seven dietary factors. Lancet 338:985-992. https://doi.org/ 10.1016/0140-6736(91)91846-M.

Urrutia, O., B. Soret, K. Insausti, J. A. Mendizabal, A. Purroy, and A. Arana. 2015. The effects of linseed or chia seed dietary supplementation on adipose tissue development, fatty acid composition, and lipogenic gene expression in lambs. Small Rumin. Res. 123:204211. https://doi.org/10.1016/j.smallrumres.2014.12.008.

Varadyova, Z., M. Certik, and D. Jalc. 2018. The possible application of fungal enriched substrates in ruminant nutrition. A review. J. Anim. Feed Sci. 27:3-10. https://doi.org/10.22358/jafs/84787/ 2018.

Vazirigohar, M., M. Dehghan-Banadaky, K. Rezayazdi, A. Nejati-Javaremi, H. Mirzaei-Alamouti, and A. K. Patra. 2018. Short communication: Effects of diets containing supplemental fats on ruminal fermentation and milk odd- and branched-chain fatty acids in dairy cows. J. Dairy Sci. 101:6133-6141. https://doi.org/10.3168/ jds.2017-14189.

Vlaeminck, B., V. Fievez, A. R. J. Cabrita, A. J. M. Fonseca, and R. J. Dewhurst. 2006. Factors affecting odd-and branched-chain fatty acids in milk: A review. Anim. Feed Sci. Technol. 131:389-417. https://doi.org/10.1016/j.anifeedsci.2006.06.017.

Wang, C. J., S. P. Wang, and H. Zhou. 2009. Influences of flavomycin, ropadiar, and saponin on nutrient digestibility, rumen fermentation, and methane emission from sheep. Anim. Feed Sci. Technol. 148:157-166. https://doi.org/10.1016/j.anifeedsci.2008.03.008.

Wang, P., S. Zhao, X. Wang, Y. Zhang, N. Zheng, and J. Wang. 2016. Ruminal methanogen community in dairy cows fed agricultural residues of corn stover, rapeseed, and cottonseed meals. J. Agric. Food Chem. 64:5439-5445. https://doi.org/10.1021/acs.jafc .6b00708.

Wencelová, M., Z. Váradyová, K. Mihaliková, K. Čobanová, I. Plachá, P. Pristaš, D. Jalč, and S. Kišidayová. 2015. Rumen fermentation pattern, lipid metabolism and the microbial community of sheep fed a high-concentrate diet supplemented with a mix of medicinal plants. Small Rumin. Res. 125:64-72. https://doi.org/10.1016/j .smallrumres.2015.01.028.

Wencelová, M., Z. Váradyová, P. Pristaš, K. Čobanová, I. Plachá, and S. Kišidayová. 2016. Effects of diet supplementation with herbal blend and sunflower seeds on fermentation parameters, microbial population, and fatty acid profile in rumen of sheep. Czech J. Anim. Sci. 61:551-559. https://doi.org/10.17221/17/2016-CJAS.

Wolin, M. J. 1960. A theoretical rumen fermentation balance. J. Dairy Sci. 43:1452-1459. https://doi.org/10.3168/jds.S0022 -0302(60)90348-9.

Zachut, M., A. Arieli, H. Lehrer, L. Livshitz, S. Yakoby, and U. Moallem. 2010. Effects of increased supplementation of n-3 fatty acids to transition dairy cows on performance and fatty acid profile in plasma, adipose tissue. J. Dairy Sci. 93:5877-5889. https://doi .org/10.3168/jds.2010-3427. 